\title{
Meteorological impacts of sea-surface temperature associated with the humid airflow from Tropical Cyclone Talas (2011)
}

\author{
M. Yamamoto \\ Research Institute for Applied Mechanics, Kyushu University, Kasuga, Japan \\ Correspondence to: M. Yamamoto (yamakatu@kyudai.jp)
}

Received: 5 December 2013 - Revised: 4 June 2014 - Accepted: 10 June 2014 - Published: 23 July 2014

\begin{abstract}
This paper examines meteorological impacts of sea-surface temperature (SST) in the presence of the humid airflow from Tropical Cyclone Talas (2011). To investigate the influence of the SST on the severe weather in and around Japan, sensitivity simulations were conducted using six SST data products covering a period of 7 days. The upward seasurface latent heat flux that accumulated over the 7-day period was high around the Kuroshio during the slow passage of the tropical cyclone. Large differences were found among the individual SST products around the southern coast of Japan. The coastal warm SST anomaly of $\sim 1.5^{\circ} \mathrm{C}$ enhanced the surface upward latent heat fluxes (by 60 to $80 \%$ ), surface southeasterly winds (by 6 to $8 \%$ ), and surface water mixing ratios (by $4 \%$ ) over the coastal sea area. The enhanced latent heat flux resulting from the coastal SST anomaly contributed to the further enhancement of the latent heat flux itself via a positive feedback with the amplified surface horizontal wind. The SST anomalies produced an anomaly in 7-day precipitation (ca. $40 \mathrm{~mm}$ ) along the mountainsides and over a coastal area where the surface wind anomaly was locally large. Thus, coastal SST error is important in the atmospheric simulation of accumulated evaporation and precipitation associated with tropical cyclones making landfall.
\end{abstract}

Keywords. Meteorology and atmospheric dynamics (mesoscale meteorology; ocean-atmosphere interactions; precipitation)

\section{Introduction}

Tropical Cyclone Talas brought heavy rain and severe winds to Japan in September 2011, and caused many deaths and severe damage. Figures 1 and 2 show the JMA (Japan Meteorological Agency) weather charts for the period
1-4 September 2011, when the cyclone passed over Japan. According to the preliminary report of the JMA released on 7 September (Japan Meteorological Agency 2011), the tropical cyclone traveled slowly northward over the Pacific between 30 August and 2 September, and made landfall over the western part of the Japanese islands at around 01:00 UTC, 3 September. After passing slowly over the main islands, the cyclone reached the Sea of Japan on 4 September, and was downgraded to an extratropical cyclone as it passed over the center of the sea. Its slow displacement and large size meant that significant amounts of moisture flowed across much of Japan over an extended period, resulting in record precipitation over mountain areas. More than $1000 \mathrm{~mm}$ of precipitation accumulated between 30 August and 6 September on the Kii Peninsula (around $34^{\circ} \mathrm{N}, 136^{\circ}$ E), with $2000 \mathrm{~mm}$ being recorded in some areas. This extremely large accumulation of rainfall caused landslides and floods. Consequently, the amount of accumulated precipitation is one of the most important meteorological elements that must be considered during hazard risk management.

The influence of sea-surface conditions on tropical and extratropical cyclogenesis has been examined in many previous studies (e.g., Chen et al., 1983; Wu et al., 2007; Yamamoto and Hirose, 2007; Katsafados et al., 2011). Although the sea-surface temperature (SST) is often important in these weather simulations, it is difficult to accurately measure high-resolution coastal SST under extreme weather conditions; for example, cloud cover is problematic for highresolution infrared observations over marginal seas. In addition, because low-frequency microwave observations produce low-resolution data, such observations cannot provide SST information along the coasts of marginal seas. To replace these missing data, daily SST data sets are processed using temporal and spatial optimum interpolation. Optimally 
(a) 0000UTC 1 Sep 2011

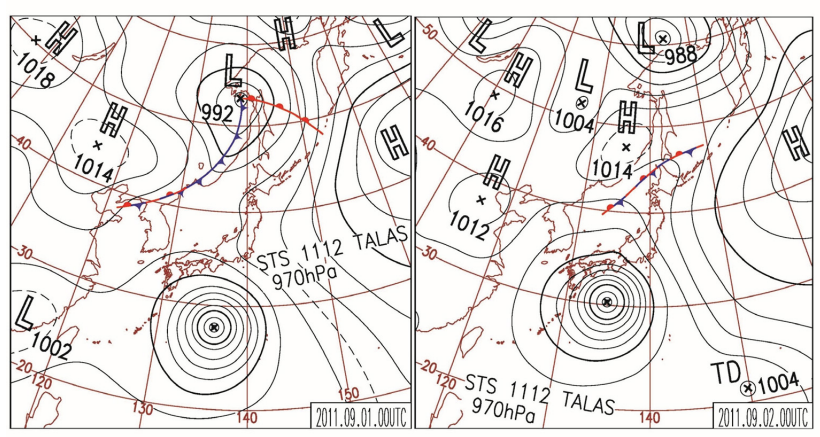

(c) 0000UTC 3 Sep 2011

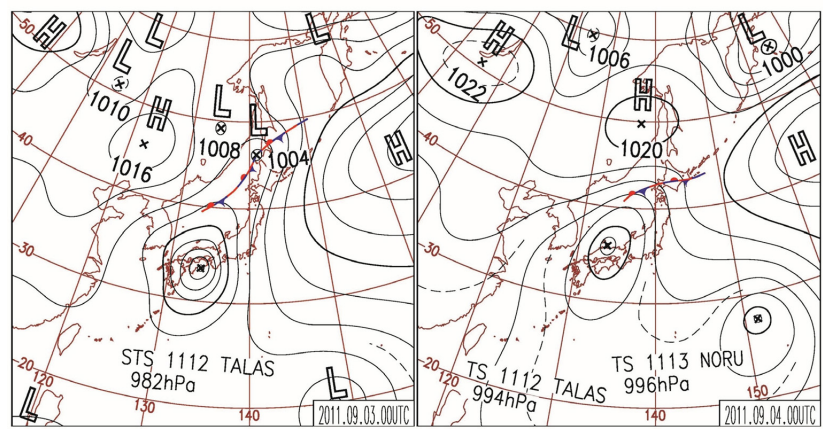

Figure 1. JMA surface weather charts at 00:00 UTC, 1-4 September 2011.

interpolated SST (OISST) data are widely applied to lowerboundary conditions in weather simulations. However, this interpolation smoothes out the high-resolution SST structures resulting from oceanic mesoscale eddies. Estimates of coastal SST are strongly dependent on the data products used (e.g., Xie et al., 2008) due to the differences in interpolation methods and resolution. Differences in coastal SST have a large influence on clouds and precipitation, and this effect has been thoroughly investigated for both cold air outbreaks and winter monsoons (Yamamoto and Hirose, 2008, 2009; Iizuka, 2010; Lee and Ryu, 2010; Xu et al., 2010; Cha et al., 2011; Yamamoto et al., 2011; Takahashi et al., 2013). However, the effects of differences in SST products on the humid summer airflows associated with tropical cyclones have yet to be fully investigated.

This paper focuses on a southeasterly warm and humid outbreak associated with a tropical cyclone in and around Japan, and aims to elucidate the influences of weekly SST anomalies on the humid airflow of Tropical Cyclone Talas in 2011. The model and data are described in Sect. 2. The simulated cyclone and its sensitivities to the SST products are discussed in Sect. 3. Because accumulation of precipitation amounts is an important factor in hazard risk management for tropical cyclones, the meteorological impacts of the SST anomalies on the 7-day accumulated precipitation and seasurface fluxes are investigated in Sect. 3.3. Finally, the results are summarized in Sect. 4.

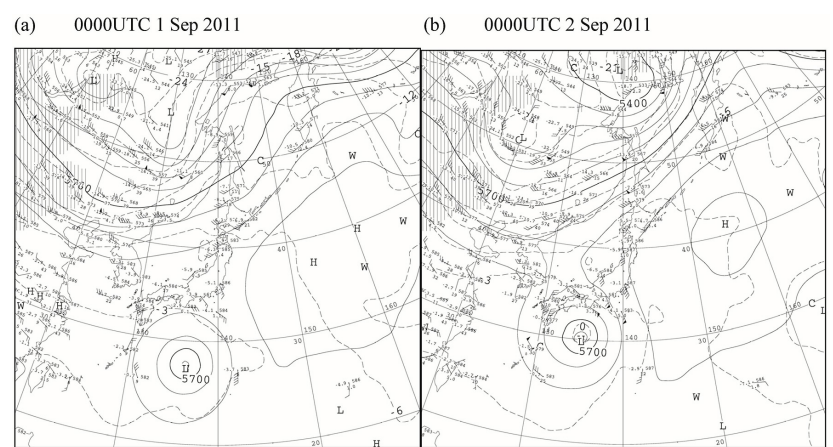

(c) 0000UTC 3 Sep 2011

(d) 0000UTC 4 Sep 2011

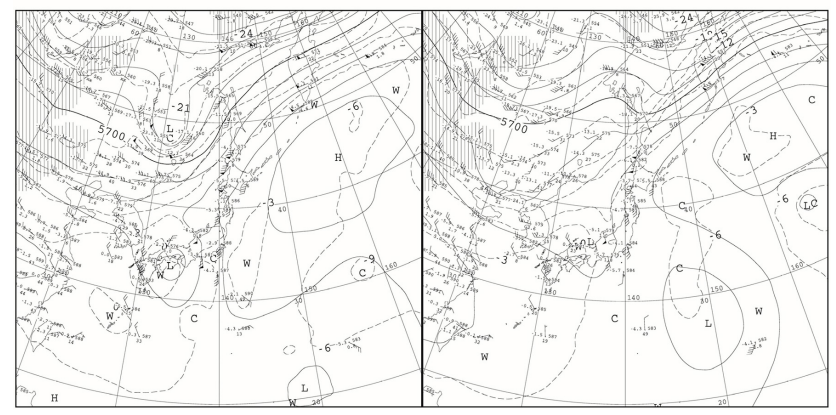

Figure 2. JMA $500 \mathrm{hPa}$ weather charts at 00:00 UTC, 1-4 September 2011.

\section{Data and model}

Seven-day simulations of Tropical Cyclone Talas were conducted using six SST products, namely, real-time global SST (RTGSST, Exp. RL), high-resolution RTG SST (RTGSST_HR, Exp. RH), Reynolds' weekly OISST (OI_Weekly, Exp. WK), OISST of AVHRR (OI_AVHRR, Exp. AV), OISST of AMSR and AVHRR (OI_AMSR + AVHRR, Exp. AA), and New Generation SST for Open Ocean ver. 1.0, Tohoku University, Japan (NGSST, Exp. NG). The resolutions and references for these data are listed in Table 1. Figure 3 shows the SSTs averaged over the six data sets in model domain, when the cyclone passed through the main Japanese islands. The standard error $(\varepsilon)$ for the six experiments is defined by $\sigma / \sqrt{N}$, where $\sigma$ is the standard deviation and $N$ is the number of SST data sets used in the model. This error indicates the difference among the six experiments. The averaged SST does not change significantly over time. The temperature is higher than $27^{\circ} \mathrm{C}$ to the south of Japan, and had strong gradients to the north of $35^{\circ} \mathrm{N}$ in the northwestern Pacific. These SST estimates differ for the various products because they depend on the resolution, satellites, and interpolation techniques used. The large standard error $\left(>0.5^{\circ} \mathrm{C}\right)$ moved from $22^{\circ} \mathrm{N}, 141^{\circ} \mathrm{E}$ at 00:00 UTC, 1 September, to $40^{\circ} \mathrm{N}, 135^{\circ} \mathrm{E}$ at 00:00 UTC, 4 September 2011, as the cyclone moved northward. Figure 4 shows the SSTs averaged over the six data sets for the period between 30 August and 5 September. Over much of 
(a) 0000UTC 1 Sep 2011

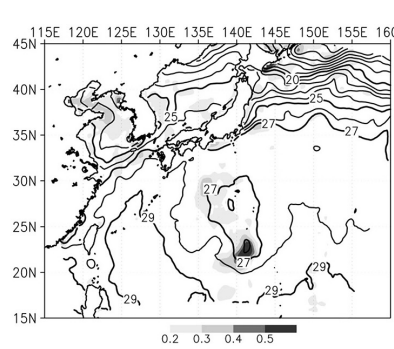

(c) 0000UTC 3 Sep 2011

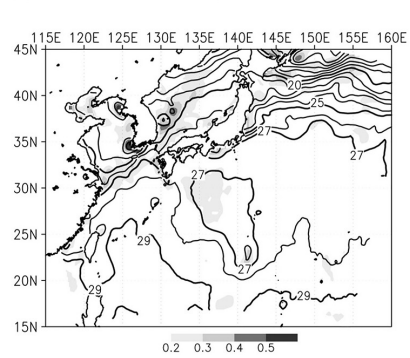

(d) 0000UTC 4 Sep 2011

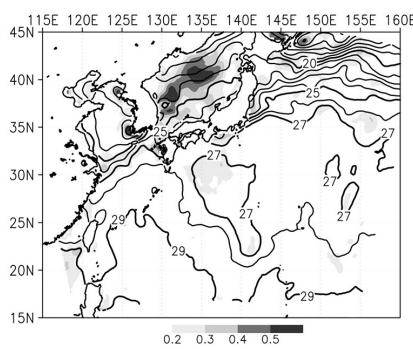

Figure 3. Distributions of the ensemble mean SST $\left({ }^{\circ} \mathrm{C}\right.$, contours) and the standard error (gray shading) for the six experiments at 00:00 UTC, 1-4 September 2011.

the open ocean (Fig. 4a), the standard errors in the average temperature are not large $\left(<0.1^{\circ} \mathrm{C}\right)$. In contrast, the errors are relatively high in the marginal sea areas and along the path of the tropical cyclone. In particular, large errors are found in the coastal areas surrounding the Japanese islands (Fig. 4b). In the cold coastal water $\left(<27^{\circ} \mathrm{C} ; 34^{\circ} \mathrm{N}\right.$, $\left.136-139^{\circ} \mathrm{E}\right)$, and along the eastern coast of the Japanese islands $\left(36^{\circ} \mathrm{N}, 141^{\circ} \mathrm{E}\right)$, the errors are greater than $0.25^{\circ} \mathrm{C}$.

The Advanced Research Weather Research Forecasting (WRF-ARW) model version 3.4.1 (Skamarock et al., 2008) was used for the sensitivity simulations, which were run from 00:00 UTC, 30 August to 00:00 UTC, 6 September 2011. The model domains are summarized in Fig. 5 and Table 2. Two-way nesting was applied to Domains $1-3$. The mother domain consists of a $141 \times 111$ horizontal grid with a resolution of $30 \mathrm{~km}$ over the Pacific region and a central latitude of $31^{\circ} \mathrm{N}$ and longitude of $137^{\circ} \mathrm{E}$ (Domain 1, Fig. 5a). The second domain consists of a $97 \times 64$ grid with a resolution of $10 \mathrm{~km}$ and covers central Japan (Domain 2, Fig. 5b). Because the precipitation was greatly underestimated over the Kii Peninsula in the test run with Domains 1 and 2, the third domain (Domain 3, Fig. 5c) with a $97 \times 137$ grid and a resolution of $2.5 \mathrm{~km}$ was established. By adding Domain 3 , the precipitation in the heavy rainfall area in Domain 2 was improved by the feedback of the high-resolution calculation in Domain 3 via the two-way nesting interaction. However, the high-resolution domain was limited to the Kii Peninsula, and did not cover the SST anomaly area along the southern coast of Japan. Thus, Domain 2 (in which the model output was improved by Domain 3) was (a)

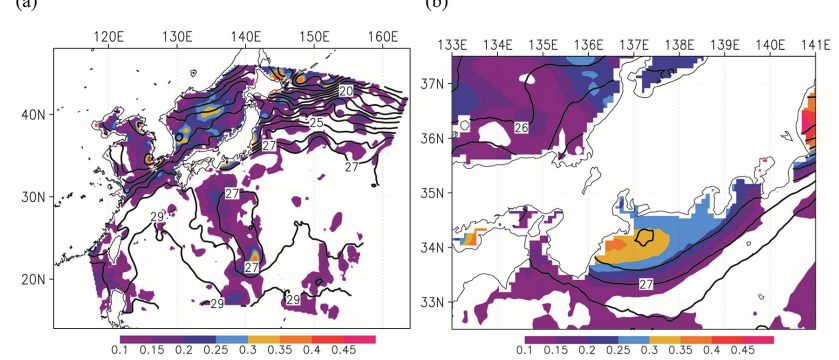

Figure 4. Distributions of the ensemble mean SST $\left({ }^{\circ} \mathrm{C}\right.$, contours) and the standard error (color shading) for the six experiments, averaged for 7 days (00:00 UTC, 30 August to 6 September 2011) (a) over the northwestern Pacific and (b) around central Japan.

considered as the analysis region in the Sects. 3.2 to 3.4. The model atmosphere between the surface and the $50 \mathrm{hPa}$ level was divided into 28 eta levels between 0 and 1 (1.0, $0.993,0.983,0.97,0.954,0.934,0.909,0.88,0.8295757$, $0.7791514,0.7287272,0.6783029,0.5917439,0.5136936$, $0.4434539,0.3803751,0.3238531,0.2733261,0.228273$, $0.18821,0.1526888,0.1212943,0.09364247,0.0693781$, $0.04817315,0.02972473,0.01375316,0.0)$. The National Centers for Environmental Prediction/Final Analyses (NCEP FNL) data sets were used as the initial and boundary conditions. To generate the lower boundary conditions over the sea, the six aforementioned SST data sets were linearly interpolated every 6 hours and the boundary conditions updated at the same interval. The present work chose the options (Skamarock et al., 2008) of WRF single-moment 6-class graupel microphysics (Hong and Lim, 2006), rapid radiative transfer model for long-wave radiation (Mlawer et al., 1997), Dudhia shortwave radiation (Dudhia, 1989), MM5 surface layer, Yonsei University planetary boundary layer (Hong et al., 2006), Kain-Fritsch cumulus (Kain, 2004), and unified Noah land surface schemes (Chen and Dudhia, 2001). The cumulus parameterization was not applied to Domain 3 because it should not be used for the resolutions of $<5 \mathrm{~km}$ (Skamarock et al., 2008).

To investigate the meteorological influence of the SST products under the realistic atmospheric conditions associated with Tropical Cyclone Talas (2011), the wind, temperature, and water vapor for all levels in Domain 1 were nudged using 3-D data from the NCEP FNL data sets every $6 \mathrm{~h}$ with coefficients of $3 \times 10^{-4} \mathrm{~s}^{-1}$ (Liu et al., 2012). The nudging was not applied to Domains 2 and 3 in the present study. In the simulations run with no nudging (Appendix A), precipitation amounts were greatly underestimated and the precipitation area differed significantly from the observations. For experiments in which both wind and temperature were nudged but water vapor was not, the precipitation was also underestimated. Therefore, this paper focuses on the simulations in which the wind, temperature, and water vapor were nudged. 
Table 1. Sea-surface temperature data sets.

\begin{tabular}{llll}
\hline Experiment & Data set name & Resolutions & References \\
\hline Exp. RL & RTG & $0.500^{\circ}, 1$ day & Thiébaux et al. (2003) \\
Exp. RH & RTG_HR & $0.083^{\circ}, 1$ day & Thiébaux et al. (2003) \\
Exp. WK & OI_Weekly & $1.000^{\circ}, 7$ days & Reynolds et al. (2002) \\
Exp. AV & OI_AVHRR & $0.250^{\circ}, 1$ day & Reynolds et al. (2007) \\
Exp. AA & OI_AMSR + AVHRR & $0.250^{\circ}, 1$ day & Reynolds et al. (2007) \\
Exp. NG & NG & $0.050^{\circ}, 1$ day & Sakaida et al. (2009) \\
\hline
\end{tabular}

Table 2. Model domains.

\begin{tabular}{llll}
\hline Domain & Grid number & Resolution & Area \\
\hline 1 & $141 \times 111$ & $30 \mathrm{~km}$ & Pacific \\
2 & $97 \times 64$ & $10 \mathrm{~km}$ & Central Japan \\
3 & $97 \times 137$ & $2.5 \mathrm{~km}$ & Kii Peninsula \\
\hline
\end{tabular}

\section{Results}

\subsection{Synoptic structures of the simulated Tropical Cyclone Talas (2011)}

The simulated sea-level pressures shown in the left-hand panels of Fig. 6 are similar to those in the JMA surface weather charts (Fig. 1). The simulated central pressures $(978 \mathrm{hPa}$ at 00:00 UTC, 1 September and $981 \mathrm{hPa}$ at 00:00 UTC, 2 September) are weaker than the observed pressure of $970 \mathrm{hPa}$ for Tropical Cyclone Talas (2011). When the center of the cyclone is located in Domain 2, the minimum pressures $(987 \mathrm{hPa}$ at 00:00 UTC, 3 September and $991 \mathrm{hPa}$ at 00:00 UTC, 4 September) are somewhat different from those in the JMA weather charts $(982 \mathrm{hPa}$ at 00:00 UTC, 3 September and $994 \mathrm{hPa}$ at 00:00 UTC, 4 September). The simulated tropical cyclone traveled slowly northward over the Pacific and made landfall over the western part of the Japanese islands at around 00:00 UTC, 3 September. After passing slowly over the islands, the cyclone reached the Sea of Japan on 4 September. The locations of central pressure are almost the same as those in the weather charts. The simulated central geopotential heights of the cyclone were $1260 \mathrm{~m}$ at $850 \mathrm{hPa}$ and $5660 \mathrm{~m}$ at $500 \mathrm{hPa}$ on 2 September. The minimum values are similar to those in the weather charts $(\sim 1200 \mathrm{~m}$ at $850 \mathrm{hPa}$ and $\sim 5640 \mathrm{~m}$ at $500 \mathrm{hPa})$. The concentric circles of the $500 \mathrm{hPa}$ height contours were broken at 00:00 UTC, 4 September, before the tropical cyclone was downgraded to an extratropical cyclone. Strong counterclockwise winds along concentric circles of sea-level pressure and geopotential height predominate around the slowly traveling cyclone. In this situation, the southeasterly wind of $>10 \mathrm{~m} \mathrm{~s}^{-1}$ flows into central Japan for an extended period. The differences among the six experiments are small (gray shading in Fig. 6) because the atmosphere in Domain 1 is (a)

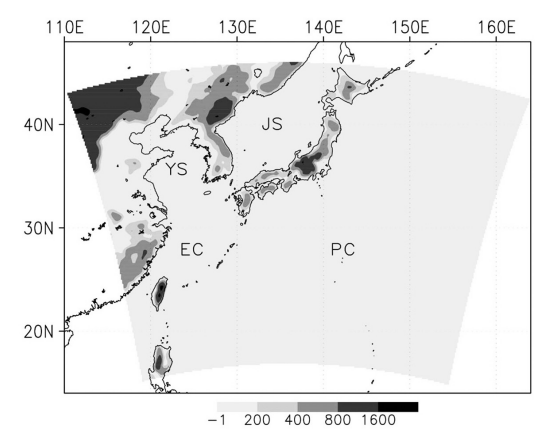

(b)

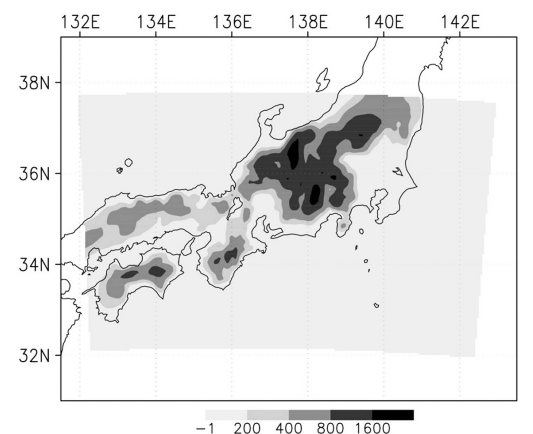

(c)

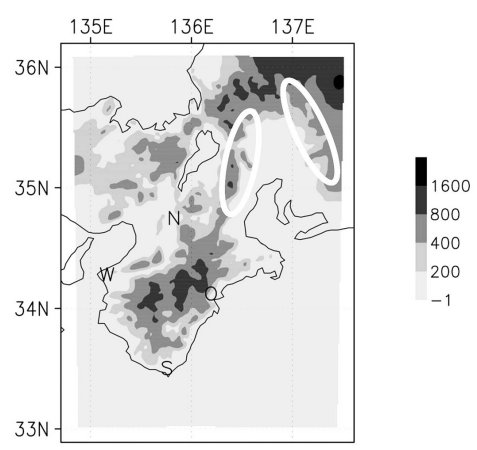

Figure 5. Distributions of elevations in (a) Domain 1, (b) Domain 2, and (c) Domain 3. JS, YS, EC, and PC indicate the Japan Sea, Yellow Sea, East China Sea, and Pacific, respectively. The observation sites at Shionomisaki (S), Owase (O), Nara (N), and Wakayama (W) are plotted in Domain 3. The white ellipse indicates the mountainsides. 
(a) 0000UTC $1 \mathrm{Sep} 2011$
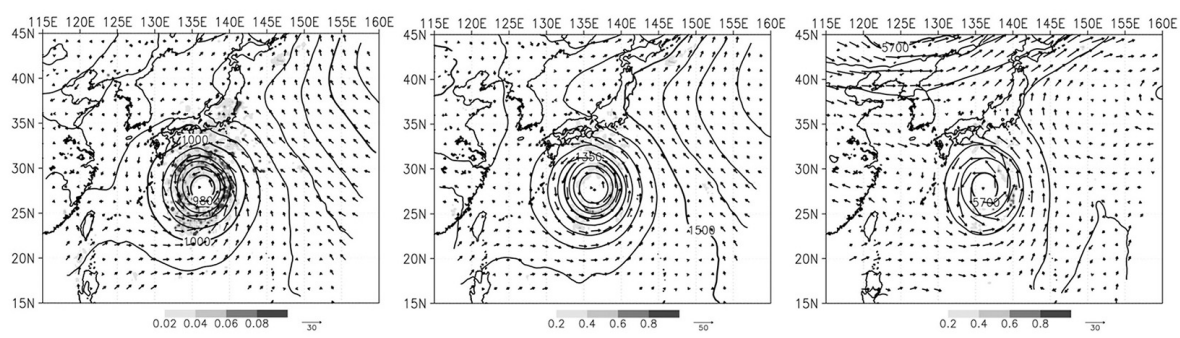

(b) 0000UTC 2 Sep 2011
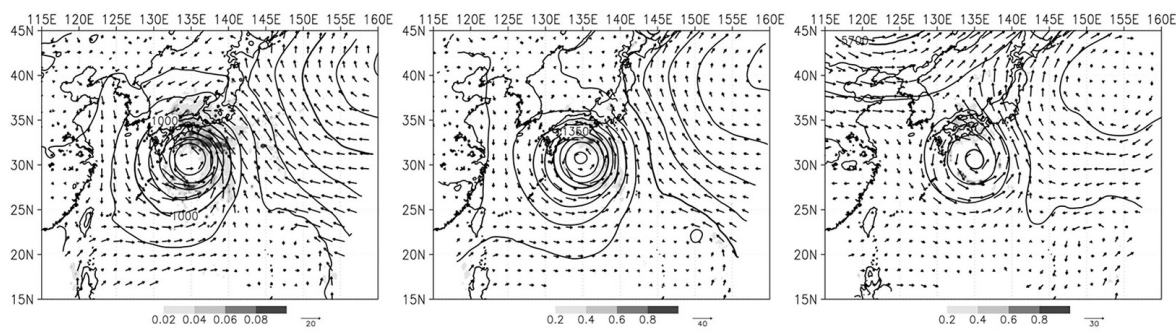

(c) 0000UTC 3 Sep 2011
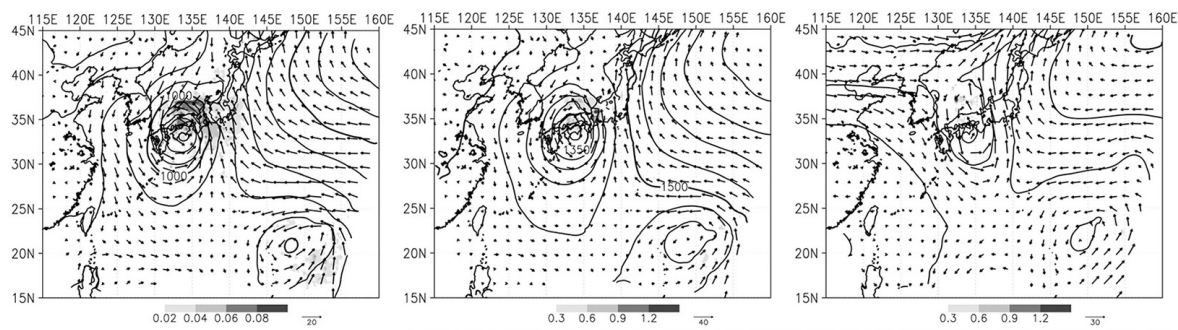

(d) 0000UTC 4 Sep 2011
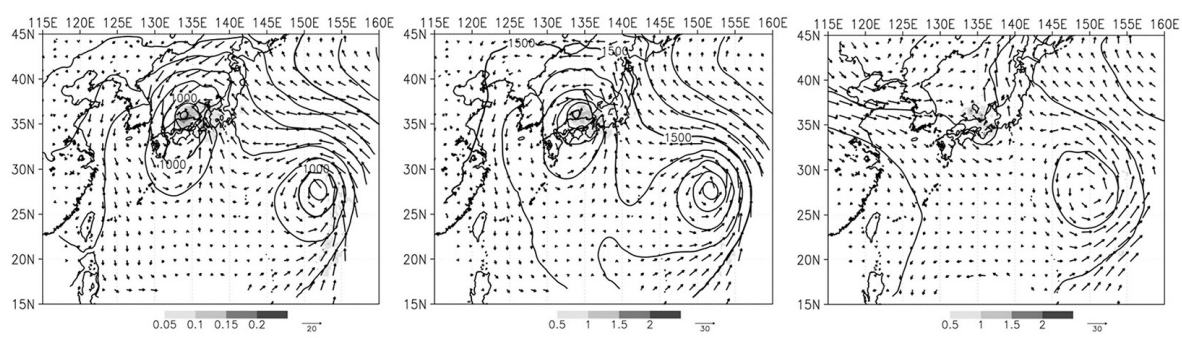

Figure 6. Distributions of ensemble mean sea-level pressure ( $\mathrm{hPa}$, left-hand panels), and $850 \mathrm{hPa}$ geopotential height (m, middle panels) and $500 \mathrm{hPa}$ geopotential height (m, right-hand panels) for the six experiments at 00:00 UTC, 1-4 September 2011. The results are obtained from the model output in Domain 1. The vector shows horizontal wind velocity, and the gray shading indicates the standard error.

nudged to the NCEP FNL data sets. The standard errors of sea-level pressure and geopotential height simulated for the ensemble experiment are less than $0.1 \mathrm{hPa}$ and $2 \mathrm{~m}$, respectively.

The time histories of minimum sea level pressures and their tracks for the six experiments are summarized in Fig. 7. The simulated minimum sea level pressures and their locations are almost the same as those in the NCEP FNL data sets. Thus, the bias in the simulated sea level pressure from the observation results from the initial conditions and 3-D data used in the nudging, which are produced from the NCEP FNL data sets. For the simulated tracks of the cyclone, we cannot see large differences among the observation and simulations around Japan after 1 September (Day 2 in Fig. 7). Thus, the standard errors caused by the difference of the cyclone structure among experiments are small through the simulations.

Figure 8 shows the temperature, water vapor, and relative vorticity at the surface, and the 850 and $500 \mathrm{hPa}$ levels at 00:00 UTC, 2 September, when the tropical cyclone is fully 
(a)

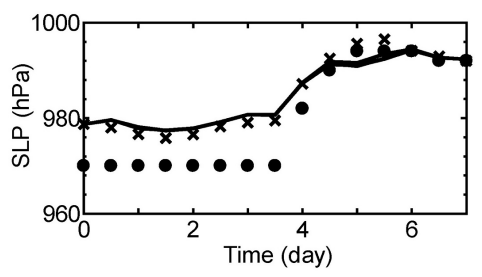

(b)

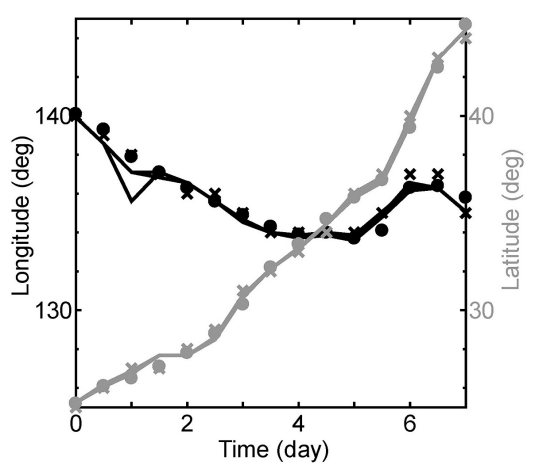

Figure 7. Time series of minimum sea-level pressure and location of Tropical Cyclone Talas (2011). The solid circles, cross marks, and lines indicate the JMA best tracks, NCEP FNL data sets, and model outputs in Domain 1 for the six experiments, respectively. The location of the cyclone is plotted by latitude (gray) and longitude (black) of the minimum sea-level pressure. Day 0 corresponds to 00:00 UTC, 30 August 2011.

developed and located to the south of Japan. A warm core is formed around the center of the cyclone. The water vapor mixing ratio surrounding the center of the cyclone is high, but decreases dramatically towards the center itself. The tropical cyclone has a high vorticity of $>150 \times 10^{-6} \mathrm{~s}^{-1}$ around the center in the low to mid-troposphere. Although the standard errors are small in the six simulations, they are seen around central Japan, north of the cyclone.

In Fig. 9, the model results are compared with the surface synoptic (SYNOP) observations on the Kii Peninsula, where the heavy precipitation occurred. The locations of the SYNOP sites are shown in Fig. 5c. The simulated sea-level pressures agree well with the observations, and are the same in all six experiments. For the air and dew-point temperatures at $2 \mathrm{~m}$ altitude, the model outputs have large differences of around $1{ }^{\circ} \mathrm{C}$ among the sensitivity experiments at Shionomisaki and Owase, whereas their differences are small at Nara and Wakayama. This implies that the model results on the southeast coast of the Kii Peninsula are strongly influenced by the SST difference. The horizontal wind magnitudes at $10 \mathrm{~m}$ altitude are overestimated at both Shionomisaki and Nara. In addition, it is difficult to accurately simulate the large fluctuations in wind directions at these four stations. These inconsistencies with the observations may be caused partly by the complex topography around the stations, which is not resolved in the model.

Figure 10 shows the upward sea-surface latent heat flux, sensible heat flux, and precipitation. The surface latent flux is high around the cyclone, where strong winds blow near the surface. The large latent flux $\left(>100 \mathrm{~W} \mathrm{~m}^{-2}\right)$ is maintained around the southern coast of Japan. The magnitude of the sea-surface sensible heat flux is much smaller than that of the latent heat flux. This is because the air temperature at $2 \mathrm{~m}$ has roughly the same value as the SST, whereas the difference between the water vapor mixing ratio at $2 \mathrm{~m}$ and seasurface saturated mixing ratio is large. The standard errors of the latent heat flux are large $(>10 \%$ of the averaged flux magnitudes) around the cyclone, where the sea-surface wind is strong. In addition, around the southern coast of Japan, the large error of $>10 \mathrm{~W} \mathrm{~m}^{-2}$ for the latent heat flux is maintained because the SST error is large. The precipitation area moves north with the cyclone, and the large precipitation of $>20 \mathrm{~mm} \mathrm{day}^{-1}$ occurs over the sea where the surface latent heat flux exceeds $200 \mathrm{~W} \mathrm{~m}^{-2}$, and also over central Japan. In particular, heavy precipitation $\left(>300 \mathrm{~mm} \mathrm{day}^{-1}\right)$ is simulated over the Kii Peninsula on 2 and 3 September.

\subsection{Seven-day mean and accumulated structures}

Figure 11 shows the 7-day JMA radar-AMeDAS (automated meteorological data acquisition system) and model precipitation estimates. Model runs and observations show similar patterns. Heavy precipitation is simulated in the present study, although it is somewhat underestimated. The 7-day precipitation amount of over $800 \mathrm{~mm}$ is greater than the monthly maximum $(692 \mathrm{~mm})$ of the JMA climatological normal value (1 km mesh data) for September (1981-2010) over the Kii Peninsula. It is difficult to simulate heavy precipitation that is locally enhanced by topography because finescale topography cannot be resolved in the low-resolution model. The present work focuses on the sensitivity of the precipitation to the different SST products. Large precipitation errors resulting from the SST differences are seen around the Pacific coast and over the Japan Sea, where the SST error is large (Fig. 4). In particular, it is locally high (>50 mm) around $33.8^{\circ} \mathrm{N}, 136.3^{\circ} \mathrm{E}$.

Figure 12 shows the surface upward latent and sensible heat fluxes accumulated for 7 days. Because the accumulated values are integrated over time, they are expressed in units of $\mathrm{MJ} \mathrm{m}^{-2}\left(=10^{6} \mathrm{~W} \mathrm{~m}^{-2} \mathrm{~s}\right)$. The accumulated upward latent heat flux (ACLHF) is higher than $100 \mathrm{MJ} \mathrm{m}^{-2}$ at the surface over the East China Sea and the coastal area of the main Japanese islands (left-hand panel of Fig. 12a). Thus, some of the moisture is supplied from the Kuroshio. The area of high ACLHF around the Kuroshio reaches the southern coast of the Kii Peninsula (around $33^{\circ}$ N, left-hand panel of Fig. 12b), where strong southeasterly and easterly winds predominate. Large errors of more than $4 \mathrm{MJ} \mathrm{m}^{-2}$ are seen over the East China and Japan seas and around the path of the cyclone. 
(a) Temperature

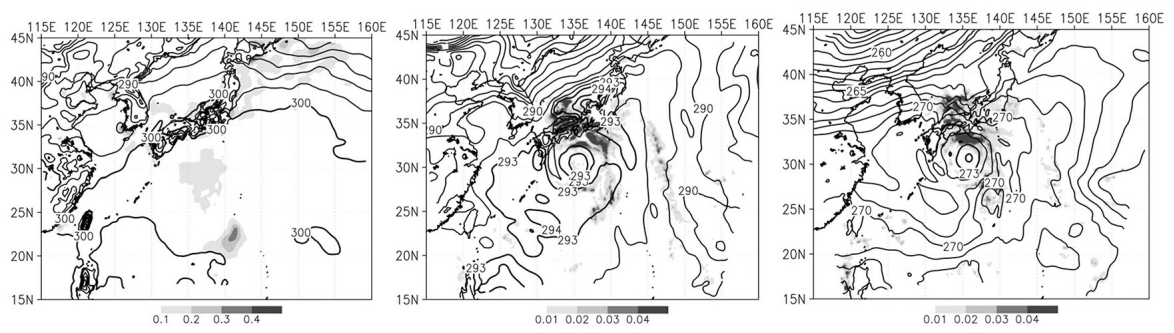

(b) Water vapor
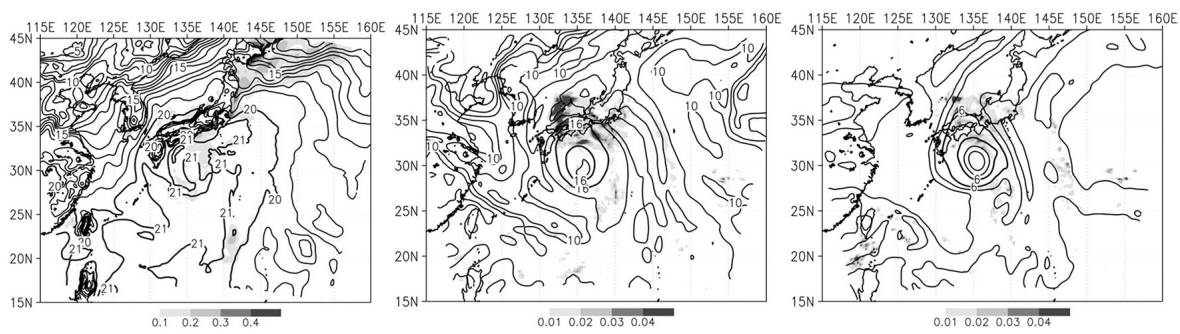

(c) Vorticity

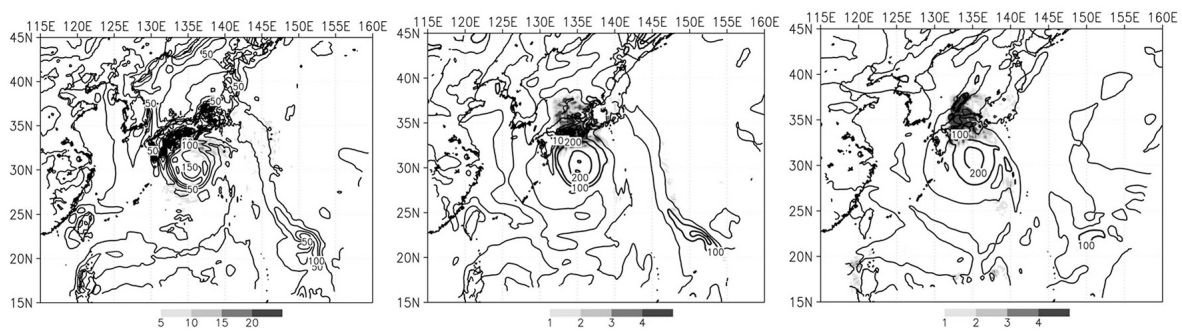

Figure 8. Distributions of ensemble mean (a) air temperature (K), (b) water vapor mixing ratio $\left(\mathrm{g} \mathrm{kg}^{-1}\right)$, and (c) relative vorticity $\left(\times 10^{-6} \mathrm{~s}^{-1}\right)$ at the surface (left-hand panels), $850 \mathrm{hPa}$ (middle panels) and $500 \mathrm{hPa}$ (right-hand panels) for the six experiments at 00:00 UTC, 2 September 2011. The results are obtained from the model output in Domain 1. The gray shading indicates the standard error.

In particular, the error is high $\left(>12 \mathrm{MJ} \mathrm{m}^{-2}\right)$ in the coastal cold-water region $\left(34^{\circ} \mathrm{N}, 136-139^{\circ} \mathrm{E}\right.$ in Fig. $\left.4 \mathrm{~b}\right)$, where the SST error is high. In contrast, the accumulated upward sensible heat flux (ACSHF) is small (one-tenth of ACLHF). The weak downward (upward) sensible heat flux is seen in the region of the relatively warm and humid southerly (cold and dry northerly) wind (Figs. 13a-15a).

The 7-day averaged air temperatures at $2 \mathrm{~m}\left(T_{2} \mathrm{~m}\right.$, Fig. 13a and b) are approximately the same as the SST over the sea. On land, $T_{2 \mathrm{~m}}$ decreases with topographical elevation. The large standard errors for the ensemble experiment are seen over the coastal area of the Pacific. The errors spread to the $950 \mathrm{hPa}$ levels around the Kii Peninsula, although they weaken with height. Water vapor mixing at $2 \mathrm{~m}\left(q_{2} \mathrm{~m}\right)$ is higher than $20 \mathrm{~g} \mathrm{~kg}^{-1}$ around the path of the tropical cyclone (Fig. 14a). The patterns of the standard error are similar to those for the surface air and sea temperatures. The error of water vapor spreads to the $950 \mathrm{hPa}$ levels over the Japan Sea and the southern coast of Japan. However, the standard error $\left(0.1 \mathrm{~g} \mathrm{~kg}^{-1}\right)$ is much smaller than the mean mixing ratio $\left(10 \mathrm{~g} \mathrm{~kg}^{-1}\right)$ although the error in the upward surface latent heat (moisture) flux is large. It seems that the standard errors of air temperature and water vapor mixing ratio at $950 \mathrm{hPa}$ are shifted towards the downstream of the coastal SST anomaly area. When water vapor is condensed over the Japanese islands, the mixing ratio is adjusted to the saturated value. Because the saturated vapor pressure is influenced by the nudged temperature in Domain 1 via the two-way nesting interaction, such an adjustment via the condensation process may also further decrease the error in the mixing ratio at $850 \mathrm{hPa}$. The horizontal moisture fluxes (gray vectors in Fig. 14) have similar pattern to the horizontal wind velocities (black vectors in Fig. 15).

The 7-day averaged horizontal winds at $10 \mathrm{~m}$ are southeasterly and have speeds $\left(U_{10 \mathrm{~m}}\right)$ of $10 \mathrm{~m} \mathrm{~s}^{-1}$ over the Pacific (Fig. 15a). The wind speed increases with height in the coastal area south of Japan (Fig. 15b-d). As shown in Figs. 13 and 14, the southeasterly wind has a high temperature and high mixing ratio. The near-surface humid airflow over the SST anomaly (Figs. 14b and c and 15b and c) is forced to flow east-southeasterly by the high mountains on the main Japanese islands (Fig. 5b), and leads to the 
(a) Shionomisaki $\left(33.45^{\circ} \mathrm{N}, 135.76^{\circ} \mathrm{E}\right)$
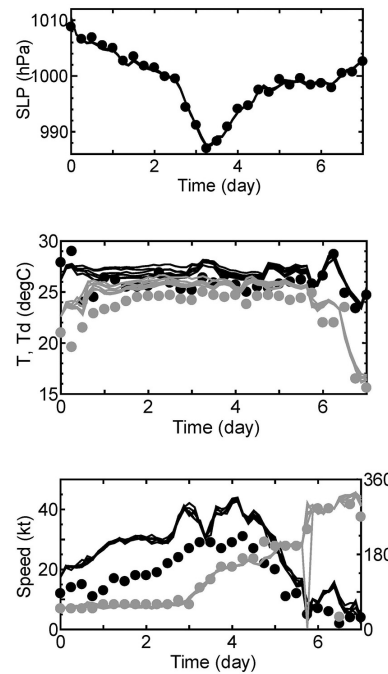

(c) $\operatorname{Nara}\left(34.69^{\circ} \mathrm{N}, 135.83^{\circ} \mathrm{E}\right)$
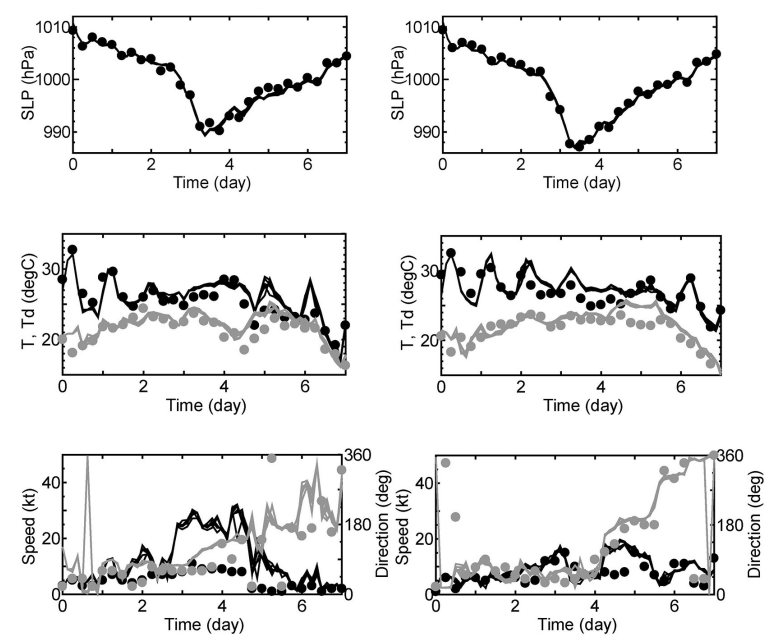

Figure 9. Time series of sea-level pressure (upper panels), air and dew point surface temperatures (middle panels), and the surface wind speed and direction (lower panels) from the observational data (solid circles) and the model outputs in Domain 3 for the six experiments (solid lines) at (a) Shionomisaki, (b) Owase, (c) Nara, and (d) Wakayama. Day 0 corresponds to 00:00 UTC, 30 August 2011. The dew point surface temperature and wind direction are shown in gray.

heavy precipitation on the Kii Peninsula (Fig. 11). The southeasterly humid airflow at $850 \mathrm{hPa}$ predominates over central Japan (Figs. 14d and 15d), and is not affected by the high mountains. The standard error of wind speed is large near the surface along the coasts. In particular, the error around $34^{\circ} \mathrm{N}$, $136.5^{\circ} \mathrm{E}$ spreads to the $950 \mathrm{hPa}$ level and advects to the northwest at $850 \mathrm{hPa}$ by upslope flow in the high elevation area. In addition to the small differences in minimum sealevel pressure and its track among the six simulations around Japan (after Day 2 in Fig. 7), the standard errors decrease with height and become trivial at $850 \mathrm{hPa}$ (Figs. 13-15). Accordingly, the near-surface standard errors in the coastal regions are primarily forced by the SST condition, not by the upper-level structures (the $850 \mathrm{hPa}$ level and higher) of the simulated cyclones.

\subsection{Meteorological impacts of the weekly SST anomaly}

Although the standard errors of the wind, temperature, and moisture are very small, the 7-day accumulated latent heat flux (evaporation) and precipitation have large standard errors for the ensemble experiment. As the errors in the evaporation and precipitation at each time step are accumulated over 7 days, the SST errors of $<0.5^{\circ} \mathrm{C}$ lead to the large errors in the accumulated evaporation and precipitation. To ascertain the cause of these large errors, the experiments with either warm or cold SST anomalies around $34^{\circ} \mathrm{N}, 136-139^{\circ} \mathrm{E}$ were investigated. In the following section, the anomaly indicates the deviation from the ensemble mean for the six experiments.

In Exp. WK (Fig. 16), the warm SST anomaly of $1^{\circ} \mathrm{C}$ is located in the coastal cold-water region $\left(34^{\circ} \mathrm{N}, 136-139^{\circ} \mathrm{E}\right)$, where the anomaly of ACLHF is larger than $40 \mathrm{MJ} \mathrm{m}^{-2}$. This corresponds to between 20 and $30 \%$ of the maximum accumulated flux (ca. $150 \mathrm{MJ} \mathrm{m}^{-2}$ ). $U_{10 \mathrm{~m}}$ is enhanced by $0.5 \mathrm{~m} \mathrm{~s}^{-1}$ around the eastern coast of the Kii Peninsula. The wind speed anomalies are 5 to $10 \%$ of the surface wind speed. The wind speed increases at $10 \mathrm{~m}$ and decreases at $950 \mathrm{hPa}$ over the positive anomaly area of ACLHF. The anomalies of $q_{2} \mathrm{~m}$ form over the coastal seas where the anomalies in ACLHF are large, and spread to the west by the advection of the humid airflow. The anomaly in $q_{2 \mathrm{~m}}$ is a few percent of the 7-day average. Unlike the 7-day accumulated latent heat flux (i.e., water vapor supply), the 7-day averaged water vapor anomaly is fairly small because the vapor immediately condenses or advects away from this sea area. The positive anomaly of the water vapor decreases with height. The anomalous moisture fluxes towards the Kii Peninsula are predominant at the surface over the coastal SST anomaly region, whereas the anomalous moisture fluxes to the upstream area of the wind are seen at $950 \mathrm{hPa}$. This implies that the horizontal moisture flux towards the Kii Peninsula is enhanced at $2 \mathrm{~m}$ level and weakened at $950 \mathrm{hPa}$.

In Exp. AV (Fig. 17), a cold SST anomaly of $0.5^{\circ} \mathrm{C}$ is seen in the coastal cold-water region $\left(34^{\circ} \mathrm{N}, 136-139^{\circ} \mathrm{E}\right)$. Although the anomalies in this case are small because of the weak SST anomaly, the signs of their anomalous patterns become reversible between experiments with the warm and cool SST anomalies. The negative SST anomaly leads to the negative anomalies of ACLHF and $q_{2} \mathrm{~m}$ over the sea. The surface wind is weakened, and the $950 \mathrm{hPa}$ wind is enhanced, via the weakened turbulent mixing in the cold-water region. The horizontal moisture flux towards the Kii Peninsula is weakened at the $2 \mathrm{~m}$ level (the anomalous vectors to the upstream area are seen in Fig. 17e). The moisture anomaly and 
(a) 0000UTC 1 Sep 2011
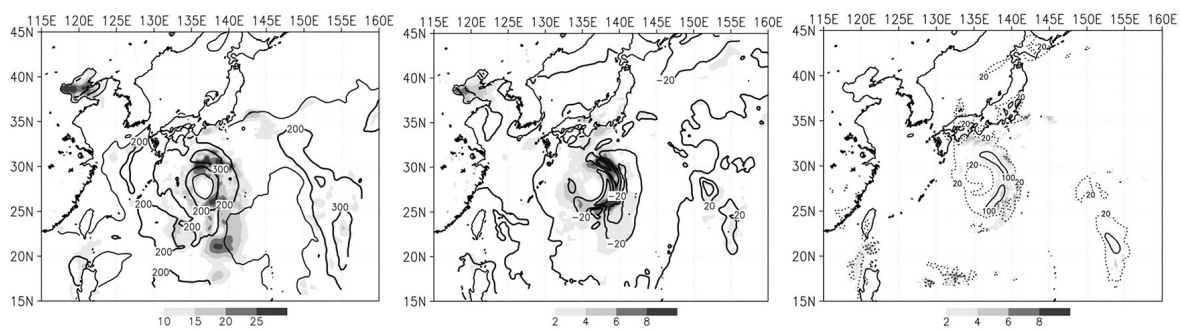

(b) $\quad$ 0000UTC 2 Sep 2011
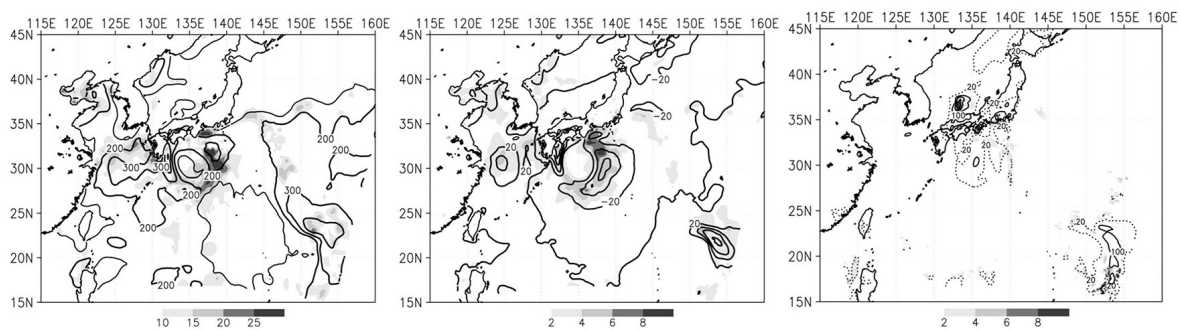

(c) 0000UTC 3 Sep 2011
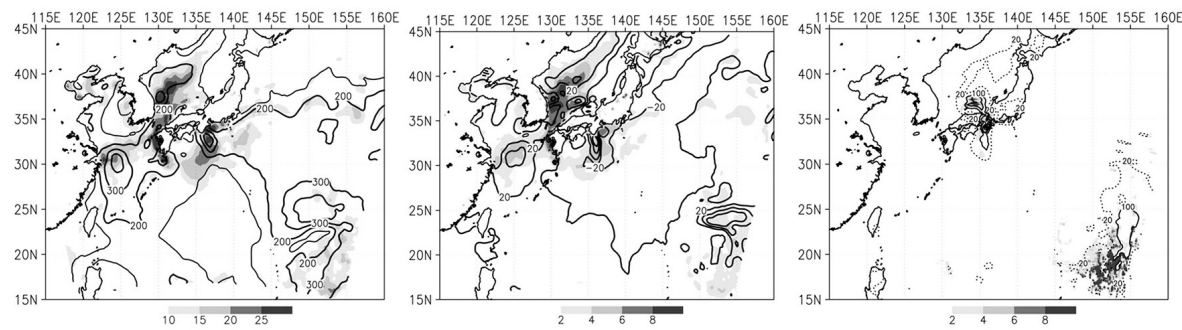

(d) $\quad 0000 \mathrm{UTC} 4$ Sep 2011
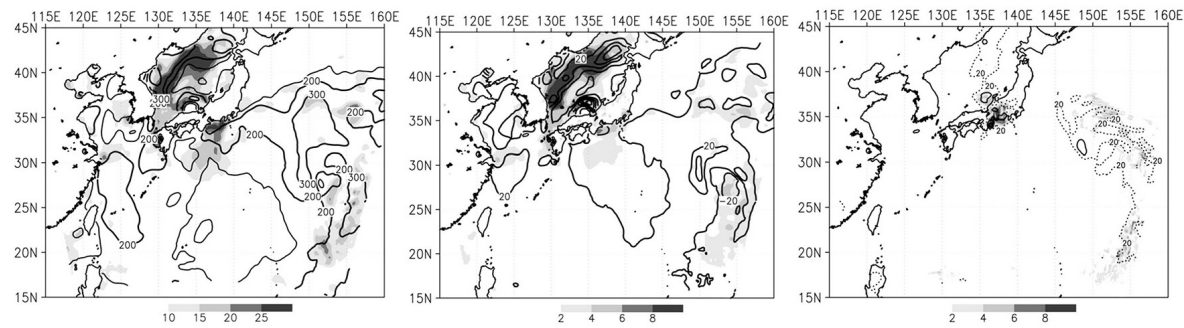

Figure 10. Distributions of ensemble mean upward sea-surface latent heat flux ( $\mathrm{W} \mathrm{m}^{-2}$, left-hand panels) and sensible heat flux (W $\mathrm{m}^{-2}$, middle panels) at 00:00 UTC, and ensemble mean $24 \mathrm{~h}$ precipitation (mm, right-hand panels) for the six experiments on 1-4 September 2011. The results are obtained from the model output in Domain 1. The gray shading indicates the standard error.

anomalous moisture flux at $950 \mathrm{hPa}$ are smaller than those near the surface.

The precipitation anomaly is large (ca. $40 \mathrm{~mm}$ ) around the large SST anomaly area. However, the anomaly pattern does not directly correspond to the pattern of the SST anomaly. The precipitation anomaly is positive in large parts of the downward area of positive SST anomaly in Exp. WK (Fig. 18a). Positive anomaly bands for precipitation are located around the mountains along $136.4^{\circ} \mathrm{E}$ and mountainsides along $137.5^{\circ} \mathrm{E}$. The two positive bands imply that precipitation is enhanced over the mountains (white ellipses in Fig. 5c) via the humid airflow. In the region between the two positive anomaly bands, precipitation has a negative anomaly. The negative band implies that the small amounts of precipitation weaken further over the small plain at around $35.2^{\circ} \mathrm{N}, 136.8^{\circ} \mathrm{E}$ (Fig. 5c). Large anomaly patches of $>80 \mathrm{~mm}$ are found around $34^{\circ} \mathrm{N}, 136.5^{\circ} \mathrm{E}$, where the horizontal wind anomalies at $10 \mathrm{~m}$ and $950 \mathrm{hPa}$ are large. The large anomalies of precipitation and wind produce the locally high errors in the area around $34^{\circ} \mathrm{N}, 136.5^{\circ} \mathrm{E}$ in Fig. 11c and Fig. 15b. On the other hand, negative precipitation anomalies of $40 \mathrm{~mm}$ are predominant in Exp. AV 
(a) OBS

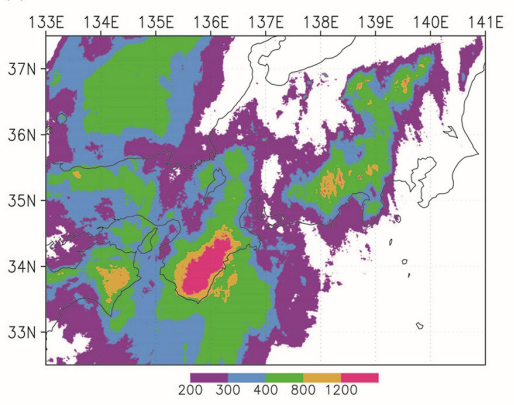

(b) Model (Average)

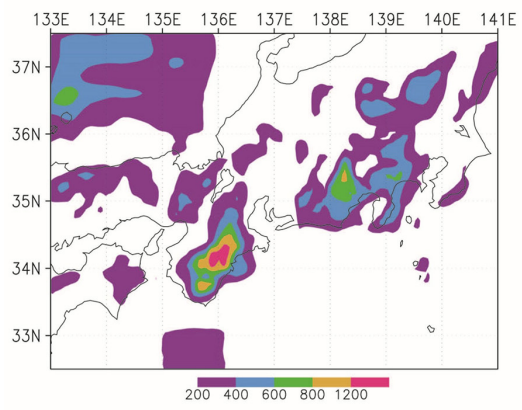

(c) Model (Standard error)

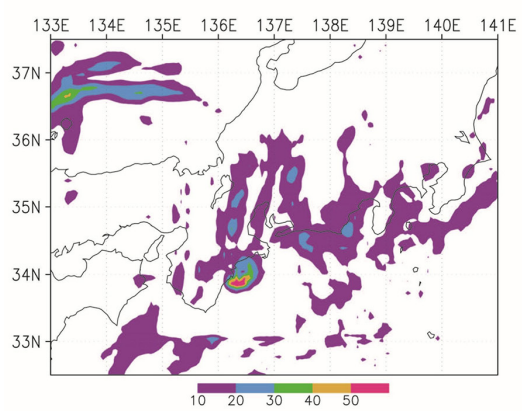

Figure 11. Distributions of accumulated precipitation (mm) from 00:00 UTC, 30 August to 6 September 2011 for (a) JMA radarAMeDAS precipitation estimates, (b) the ensemble mean for the six simulations, and (c) its standard error. The model results are obtained from the output in Domain 2.

(Fig. 18b). The precipitation is weakened around the mountains along $136.4^{\circ} \mathrm{E}$ and mountainsides along $137.5^{\circ} \mathrm{E}$.

The precipitation anomalies are produced by the SST anomalies not only in the coastal regions but probably also around the path of the cyclone, where latent heat flux is high. It is difficult to separate the effects of the coastal and Pacific SSTs on precipitation because the precipitation may be sensitive to temporarily subtle differences in the meteorological quantities at upper levels among the six experiments. Thus, the anomaly pattern of precipitation may become complex.

As mentioned above, (i) the Pacific SST anomaly is relatively smaller than the coastal SST ones, (ii) the differences of simulated cyclones are also small in six experiments (a) ACLHF

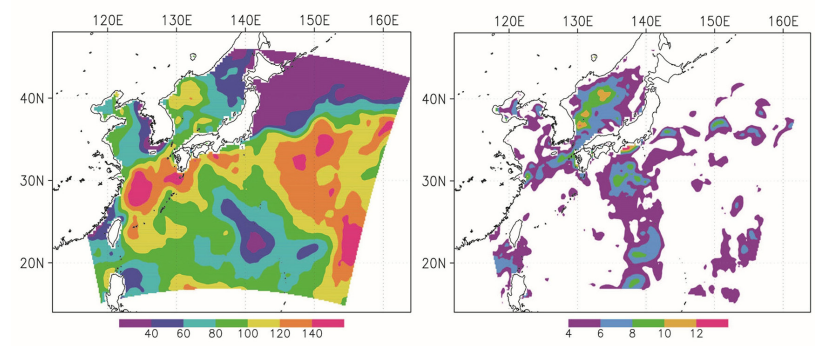

(b) ACLHF
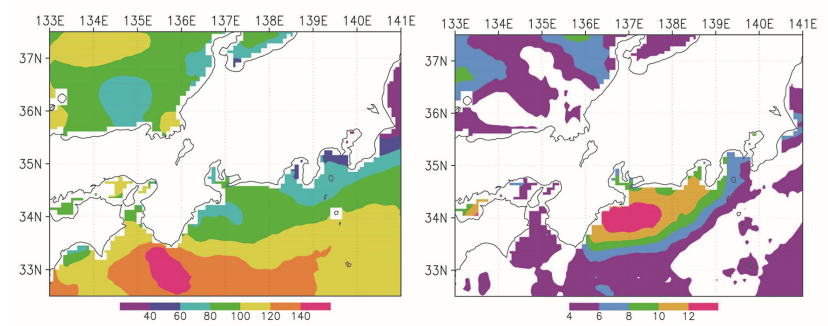

(c) ACSHF

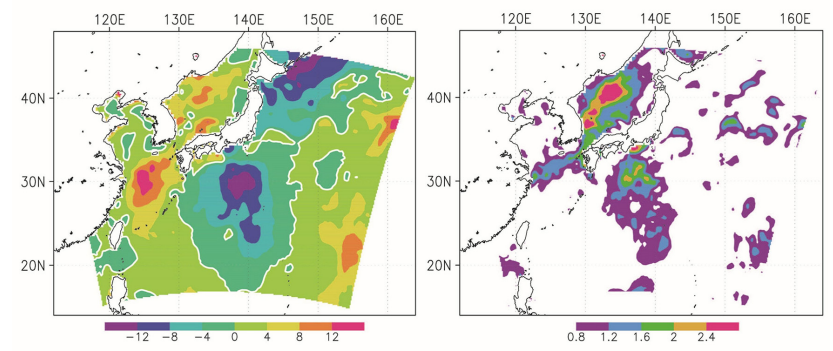

Figure 12. Distributions of ensemble means (left-hand panels) and standard errors (right-hand panels) of (a) upward latent heat flux at the sea surface $\left(\mathrm{MJ} \mathrm{m}^{-2}\right)$ over the northwestern Pacific (Domain 1), (b) latent heat flux around central Japan (Domain 2), and (c) sensible heat flux over the northwestern Pacific. The upward surface heat fluxes are accumulated over 7 days (00:00 UTC, 30 August to 6 September 2011).

because of nudging (Figs. 6 and 8), and (iii) the strong coastal anomaly patches of $q_{2} \mathrm{~m}, T_{2} \mathrm{~m}$, and $U_{10 \mathrm{~m}}$ are confined over the coastal SST patch. Thus, we can discuss the local influence of the coastal SST patches on the surface heat fluxes because (iv) the surface heat fluxes are determined by the seasurface condition and near-surface ( 2 or $10 \mathrm{~m}$ ) atmospheric condition. Although we do not, of course, neglect the effect of the Pacific SST, the coastal SST is primarily important in the formation of the coastal surface heat fluxes because of reasons (i) to (iv). In the six experiments, the latent heat flux anomalies over the SST anomaly are fairly large. To quantitatively discuss the influence of the SST on the coastal surface latent heat flux, Tables 3 and 4 show the ensemble means and anomalies of 7-day averaged surface meteorological elements in the six experiments at $34.0^{\circ} \mathrm{N}$, $136.8^{\circ} \mathrm{E}$, where the standard error of SST is high around the eastern coast of the Kii Peninsula (Fig. 4b). The anomalies of $T_{2 \mathrm{~m}}$ and SST $-T_{2 \mathrm{~m}}$ are somewhat smaller than those 
Table 3. Ensemble means and anomalies of 7-day averaged surface meteorological elements at $34.0^{\circ} \mathrm{N}, 136.8^{\circ} \mathrm{E}$.

\begin{tabular}{lrrrrrrrrr}
\hline $\begin{array}{l}\text { Quantity } \\
\text { Unit }\end{array}$ & $\begin{array}{r}\mathrm{SST} \\
{ }^{\circ} \mathrm{C}\end{array}$ & $\begin{array}{r}T_{2 \mathrm{~m}} \\
{ }^{\circ} \mathrm{C}\end{array}$ & $\begin{array}{r}q_{\mathrm{sat}} \\
\mathrm{g} \mathrm{kg}^{-1}\end{array}$ & $\begin{array}{r}q_{2 \mathrm{~m}} \\
\mathrm{~g} \mathrm{~kg}^{-1}\end{array}$ & $\begin{array}{r}U_{10 \mathrm{~m}} \\
\mathrm{~m} \mathrm{~s}^{-1}\end{array}$ & $\begin{array}{r}\mathrm{SST}-T_{2 \mathrm{~m}} \\
{ }^{\circ} \mathrm{C}\end{array}$ & $\begin{array}{r}q_{\mathrm{sat}}-q_{2 \mathrm{~m}} \\
\mathrm{~g} \mathrm{~kg}^{-1}\end{array}$ & $\begin{array}{r}\mathrm{ACSHF} \\
\mathrm{M} \mathrm{Jm}^{-2}\end{array}$ & $\begin{array}{r}\mathrm{ACLHF} \\
\mathrm{M} \mathrm{Jm}^{-2}\end{array}$ \\
\hline Mean & 26.09 & 26.40 & 21.77 & 19.36 & 12.69 & -0.31 & 2.42 & -9.66 & 79.85 \\
Exp. RL & +0.17 & +0.06 & +0.20 & +0.03 & +0.09 & +0.11 & +0.17 & +1.59 & +7.84 \\
Exp. RH & -0.27 & -0.15 & -0.38 & -0.12 & -0.16 & -0.12 & -0.26 & -2.95 & -12.94 \\
Exp. WK & +1.61 & +0.93 & +2.21 & +0.78 & +1.04 & +0.68 & +1.43 & +13.21 & +64.47 \\
Exp. AV & -0.91 & -0.59 & -1.20 & -0.45 & -0.56 & -0.32 & -0.75 & -5.80 & -33.98 \\
Exp. AA & -0.90 & -0.55 & -1.20 & -0.44 & -0.52 & -0.35 & -0.76 & -6.06 & -33.53 \\
Exp. NG & +0.30 & +0.29 & +0.38 & +0.20 & +0.11 & +0.01 & +0.18 & +0.01 & +8.13 \\
\hline
\end{tabular}

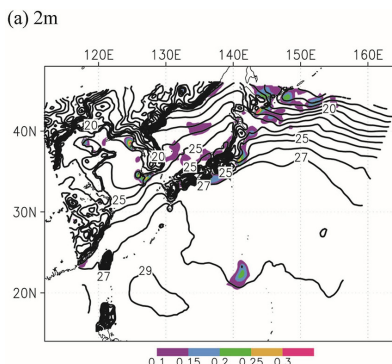

(b) $2 \mathrm{~m}$

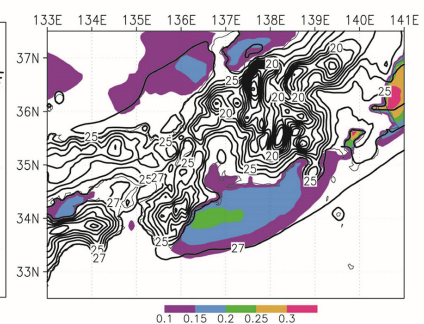

(c) $950 \mathrm{hPa}$

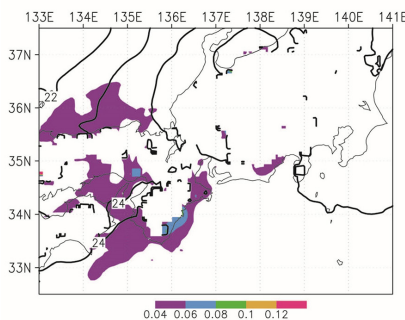

(d) $850 \mathrm{hPa}$

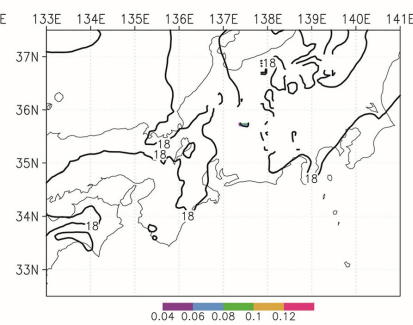

Figure 13. Distributions of ensemble means (contours) and standard errors (color shading) of air temperature (K) (a) at $2 \mathrm{~m}$ over the northwestern Pacific (Domain 1), (b) at $2 \mathrm{~m}$ around central Japan (Domain 2), (c) at $950 \mathrm{hPa}$ around central Japan, and (d) at $850 \mathrm{hPa}$ around central Japan. The air temperatures are averaged over 7 days (00:00 UTC, 30 August to 6 September 2011).

of SST, and the anomalies of $q_{2} \mathrm{~m}$ are also not large ( -2 to $4 \%$ of $\left.19.36 \mathrm{~g} \mathrm{~kg}^{-1}\right)$. In contrast, the anomalies of $q_{\mathrm{sat}}-q_{2 \mathrm{~m}}$ are -32 to $59 \%$ of $2.42 \mathrm{~g} \mathrm{~kg}^{-1}$ (where $q_{\text {sat }}$ is surface saturated mixing ratio), and larger than those of $q_{2} \mathrm{~m}$, except for Exp. NG. For $U_{10 \mathrm{~m}}$, the SST anomalies lead to the differences of -4 to $+8 \%$.

In Exp. WK, compared to the anomaly of $q_{2} \mathrm{~m}(4 \%)$, the anomaly of $q_{\mathrm{sat}}-q_{2 \mathrm{~m}}$ is fairly large (59\%) and that of $U_{10 \mathrm{~m}}$ is large $(8 \%)$. Because the surface latent heat flux is proportional to $q_{\mathrm{sat}}-q_{2 \mathrm{~m}}$ and $U_{10 \mathrm{~m}}$, it is strongly enhanced by $80 \%$ at $34.0^{\circ} \mathrm{N}, 136.8^{\circ} \mathrm{E}$ by the strong warm SST anomaly of $1.6^{\circ} \mathrm{C}$. The cold SST anomalies $\left(-0.9^{\circ} \mathrm{C}\right.$ in Exp. AV and Exp. AA) weaken the surface latent heat flux $(-42 \%)$ via weakness of $U_{10 \mathrm{~m}}(-4 \%)$ and $q_{\mathrm{sat}}-q_{2 \mathrm{~m}}(-31 \%)$. Thus, the latent heat flux is mainly controlled by $q_{\mathrm{sat}}-q_{2 \mathrm{~m}}$ and

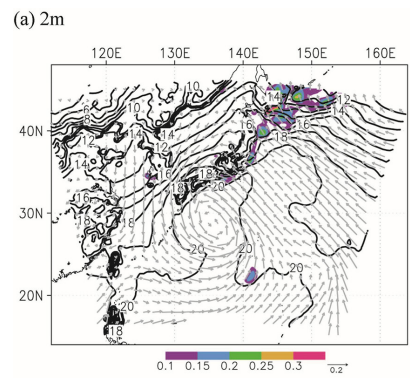

(b) $2 \mathrm{~m}$

(c) $950 \mathrm{hPa}$
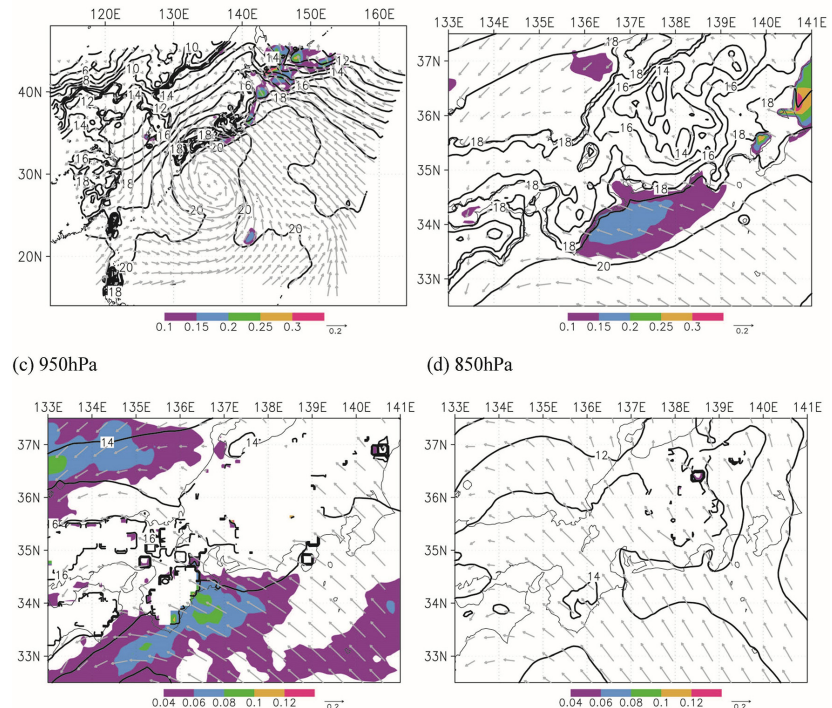

(d) $850 \mathrm{hPa}$

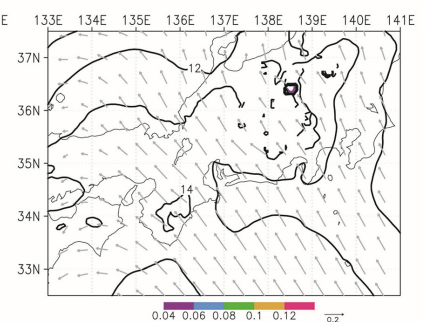

Figure 14. Distributions of ensemble means (contours) and standard errors (color shading) of water vapor mixing ratios $\left(\mathrm{g} \mathrm{kg}^{-1}\right)$ (a) at $2 \mathrm{~m}$ over the northwestern Pacific (Domain 1), (b) at $2 \mathrm{~m}$ around central Japan (Domain 2), (c) at $950 \mathrm{hPa}$ around central Japan, and (d) at $850 \mathrm{hPa}$ around central Japan. The water vapor mixing ratios are averaged over 7 days (00:00 UTC, 30 August to 6 September 2011). The gray vector shows the horizontal moisture flux.

additionally by $U_{10 \mathrm{~m}}$. The large positive (negative) anomaly of the upward surface turbulent heat flux in the coastal area enhances (weakens) vertical momentum mixing from the strong upper-level southeasterly wind, which induces the anomaly of the southeasterly (northwesterly) (e.g., Hayes et al., 1989; Wallace et al., 1989). In particular, wind magnitude differences of around $0.5 \mathrm{~m} \mathrm{~s}^{-1}$ dominate in the coastal warm anomaly area for Exp. WK. The enhanced latent heat flux resulting from the coastal SST anomaly contributes to the further enhancement of the latent heat flux itself via the increased surface horizontal wind. This implies a positive feedback between the surface latent heat flux and horizontal wind. 
(a) $10 \mathrm{~m}$

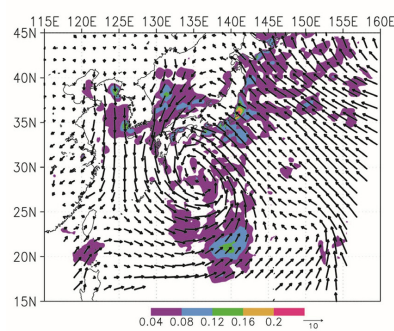

(c) $950 \mathrm{hPa}$

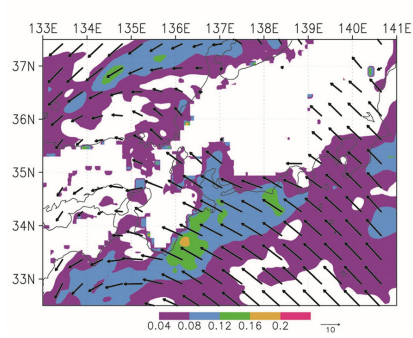

(b) $10 \mathrm{~m}$

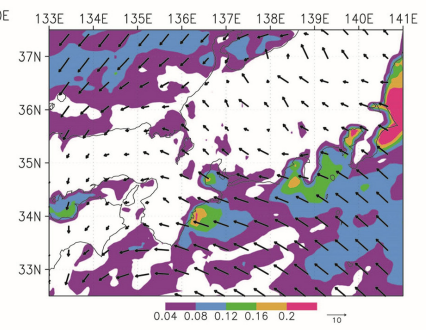

(d) $850 \mathrm{hPa}$

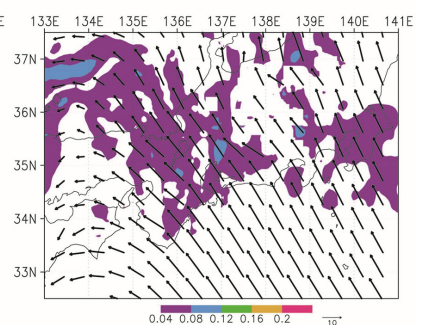

Figure 15. Distributions of ensemble mean horizontal winds $\left(\mathrm{m} \mathrm{s}^{-1}\right.$, vectors) and standard errors of the wind speeds (color shading) (a) at $2 \mathrm{~m}$ over the northwestern Pacific (Domain 1), (b) at $2 \mathrm{~m}$ around central Japan (Domain 2), (c) at $950 \mathrm{hPa}$ around central Japan, and (d) at $850 \mathrm{hPa}$ around central Japan. The horizontal winds are averaged over 7 days (00:00 UTC, 30 August to 6 September 2011).

To check the sensitivity to the analysis area, the representative point $\left(34^{\circ} \mathrm{N}, 136.8^{\circ} \mathrm{E}\right.$, Table 4$)$ is extended to the coastal area $\left(33.5-34.0^{\circ} \mathrm{N}, 136.8-137.3^{\circ} \mathrm{E}\right.$, Table 5) where the standard error of SST is large in Fig. 4b. The results are similar between Tables 4 and 5, although the magnitudes of the anomalies are somewhat small in Table 5. On the other hand, the anomalies of the surface meteorological elements at the upstream point $\left(33.0^{\circ} \mathrm{N}, 138.5^{\circ} \mathrm{E}\right.$, Table 6) are smaller than those at the representative point. In particular, these anomalies in Exp. WK and Exp. AV are small outside the coastal area of the large SST error. Thus, we can confirm that the large near-surface anomalies in the coastal regions are primarily forced by the coastal SST, not by the upstream SST.

The air-sea temperature difference $\left(\mathrm{SST}-T_{2} \mathrm{~m}\right)$ is $-0.31^{\circ} \mathrm{C}$ at the representative point (Table 3 ), while it is $-0.01^{\circ} \mathrm{C}$ at the upstream point (Table 6). Because $T_{2} \mathrm{~m}$ is almost the same as SST in and around the representative point, the surface air temperature has already mostly been adjusted to SST via the enhanced heat exchange due to the strong surface wind over the Pacific. Thus, the anomaly of SST $-T_{2} \mathrm{~m}$ is also not large in the representative and upstream points.

In contrast to the small air-sea temperature difference, the large air-sea difference of water vapor mixing ratio $\left(q_{\text {sat }}-q_{2 \mathrm{~m}}\right)$ is maintained via continuously strong advection of the unsaturated water vapor, although the airsea exchange of the water vapor is enhanced by the strong surface wind. The air-sea difference of water vapor

(a) SST

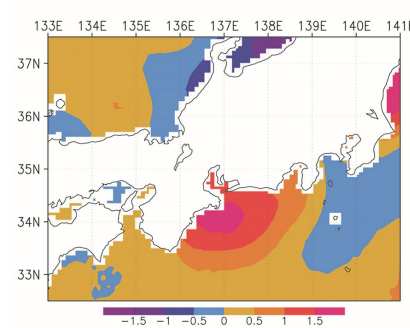

(b) ACLHF

(c) WND10m

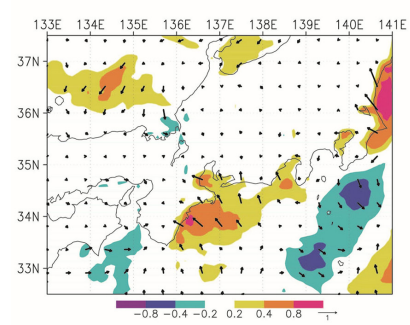

(e) $\mathrm{q} 2 \mathrm{~m}$
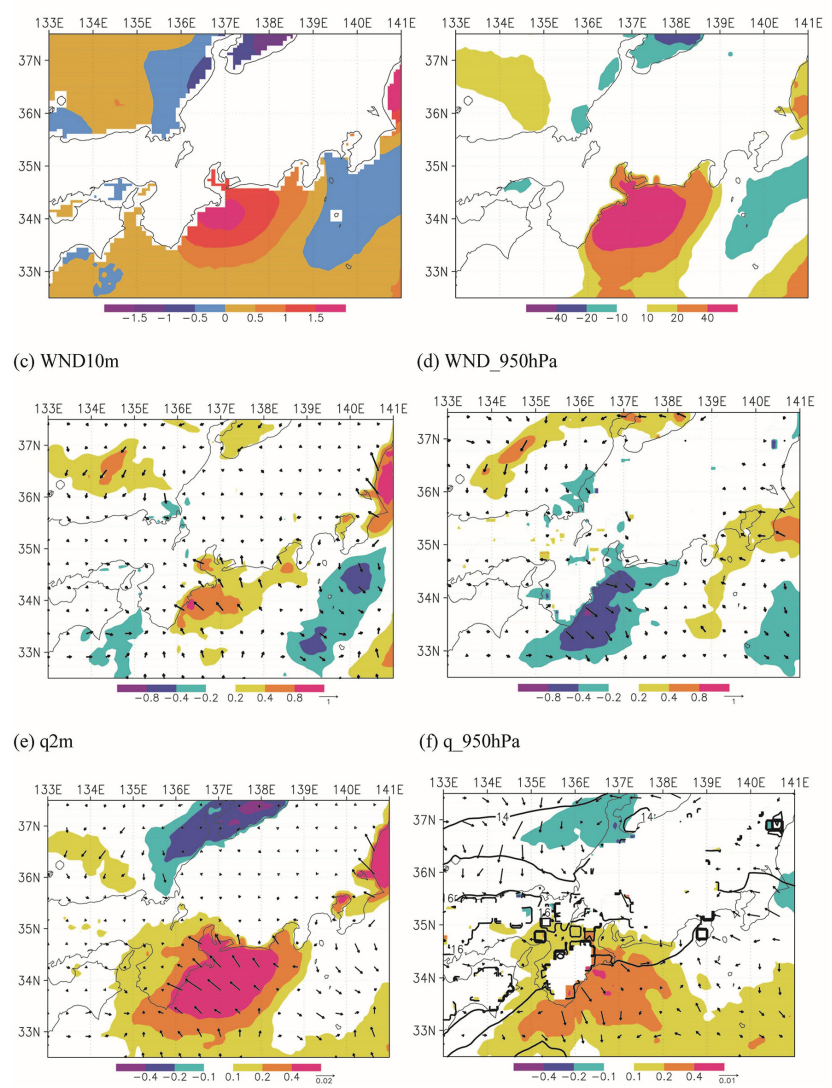

(d) WND 950hPa

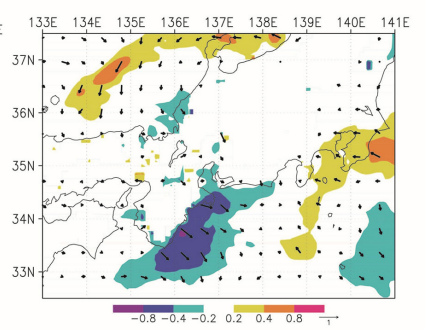

(f) q_950hPa

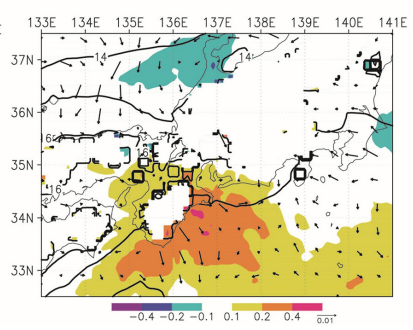

Figure 16. Distributions of anomalies (color shading) with respect to the ensemble mean for 7 days (00:00 UTC, 30 August to 6 September 2011) for (a) mean SST $\left({ }^{\circ} \mathrm{C}\right)$, (b) accumulated latent heat flux $\left(\mathrm{MJ} \mathrm{m}^{-2}\right)$ at the sea surface, (c) mean horizontal wind magnitude $\left(\mathrm{m} \mathrm{s}^{-1}\right)$ at $10 \mathrm{~m}$, (d) mean horizontal wind magnitude at $950 \mathrm{hPa}$, (e) water vapor mixing ratio $\left(\mathrm{g} \mathrm{kg}^{-1}\right)$ at $2 \mathrm{~m}$, and (f) water vapor mixing ratio at $950 \mathrm{hPa}$ in Exp. WK (Domain 2). The vectors show the anomalous horizontal wind velocity in (c) and (d) and the anomalous horizontal moisture flux in (e) and (f).

Table 4. Percentages of 7-day averaged surface anomalies from the ensemble means at $34.0^{\circ} \mathrm{N}, 136.8^{\circ} \mathrm{E}$.

\begin{tabular}{lrrr}
\hline & $U_{10 \mathrm{~m}}(\%)$ & $q_{\mathrm{sat}}-q_{2 \mathrm{~m}}(\%)$ & ACLHF $(\%)$ \\
\hline Exp. RL & 0.72 & 7.00 & 9.82 \\
Exp. RH & -1.25 & -10.94 & -16.20 \\
Exp. WK & 8.16 & 59.19 & 80.74 \\
Exp. AV & -4.38 & -31.12 & -42.55 \\
Exp. AA & -4.12 & -31.51 & -41.99 \\
Exp. NG & 0.86 & 7.37 & 10.18 \\
\hline
\end{tabular}

mixing ratio is $2.42 \mathrm{~g} \mathrm{~kg}^{-1}$ at a representative point (Table 3) and $3.32 \mathrm{~g} \mathrm{~kg}^{-1}$ at the upstream point (Table 6). Thus, differently from $T_{2} \mathrm{~m}, q_{2} \mathrm{~m}$ has not been adjusted to $q_{\text {sat }}$. The surface saturated vapor pressure governed by the Clausius-Clapeyron equation exponentially changes with 
(a) SST

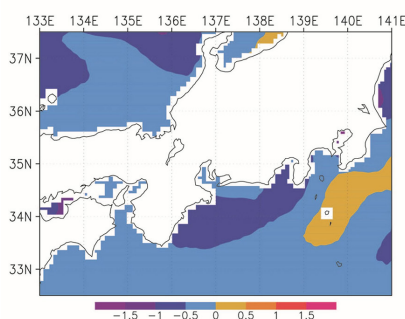

(c) WND10m

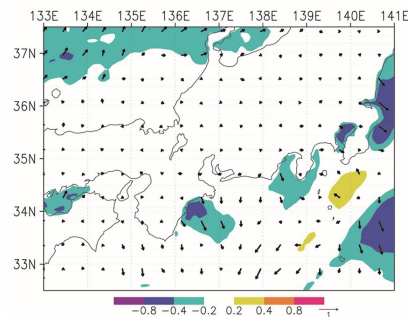

(e) $\mathrm{q} 2 \mathrm{~m}$

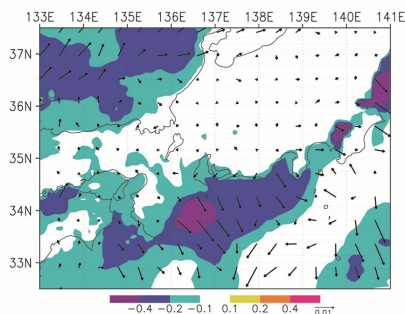

(b) ACLHF

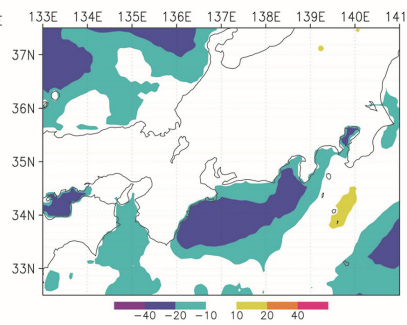

(d) WND_950hPa

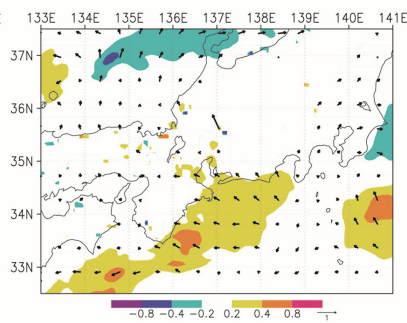

(f) q $950 \mathrm{hPa}$

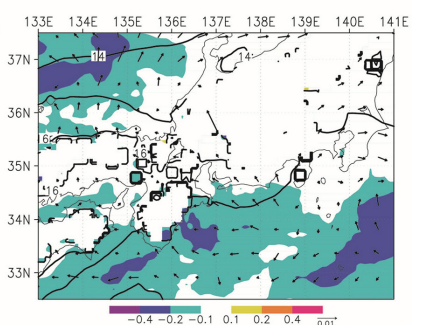

Figure 17. Distributions of anomalies (color shading) with respect to the ensemble mean for 7 days (00:00 UTC, 30 August to 6 September 2011) for (a) mean SST $\left({ }^{\circ} \mathrm{C}\right)$, (b) accumulated latent heat flux $\left(\mathrm{MJ} \mathrm{m}^{-2}\right)$ at the sea surface, (c) mean horizontal wind magnitude $\left(\mathrm{m} \mathrm{s}^{-1}\right)$ at $10 \mathrm{~m},(\mathbf{d})$ mean horizontal wind magnitude at $950 \mathrm{hPa},(\mathbf{e})$ water vapor mixing ratio $\left(\mathrm{g} \mathrm{kg}^{-1}\right)$ at $2 \mathrm{~m}$, and (f) water vapor mixing ratio at $950 \mathrm{hPa}$ in Exp. AV (Domain 2). The vectors show the anomalous horizontal wind velocity in (c) and (d) and the anomalous horizontal moisture flux in (e) and (f).

SST anomaly (Takahashi et al., 2013), whereas the unsaturated air mass is advected from the upstream area to the coastal area. As a result, the anomaly of $q_{\mathrm{sat}}$ is 2-3 times larger than that of $q_{2 \mathrm{~m}}$, although there are a few exceptions. This indicates that, compared to $q_{2 \mathrm{~m}}, q_{\mathrm{sat}}$ is sensitive to the SST anomaly via the exponential change in the surface saturated vapor pressure. Thus, the anomalies of $q_{\mathrm{sat}}-q_{2 \mathrm{~m}}$ become large via the large change in $q_{\text {sat }}$ caused by the SST anomaly.

\subsection{Time evolutions of meteorological influences of the coastal SST anomaly}

Figure 19 shows the ensemble means of surface meteorological elements and their anomalies in Exp. WK and Exp. AV at the representative point $\left(34^{\circ} \mathrm{N}, 136.8^{\circ} \mathrm{E}\right)$. The surface horizontal wind is easterly before the cyclone landing on the
Table 5. Percentages of 7-day averaged surface anomalies from the ensemble means, averaged over a domain of $33.5-34.0^{\circ} \mathrm{N}$ and $136.8-137.3^{\circ} \mathrm{E}$.

\begin{tabular}{lrrr}
\hline & $U_{10 \mathrm{~m}}(\%)$ & $q_{\mathrm{sat}}-q_{2 \mathrm{~m}}(\%)$ & ACLHF $(\%)$ \\
\hline Exp. RL & 0.85 & 0.16 & 2.07 \\
Exp. RH & -0.82 & -9.51 & -12.75 \\
Exp. WK & 6.16 & 50.25 & 65.38 \\
Exp. AV & -3.40 & -24.57 & -31.99 \\
Exp. AA & -3.23 & -22.36 & -29.41 \\
Exp. NG & 0.45 & 6.02 & 6.70 \\
\hline
\end{tabular}

(a)

(b)
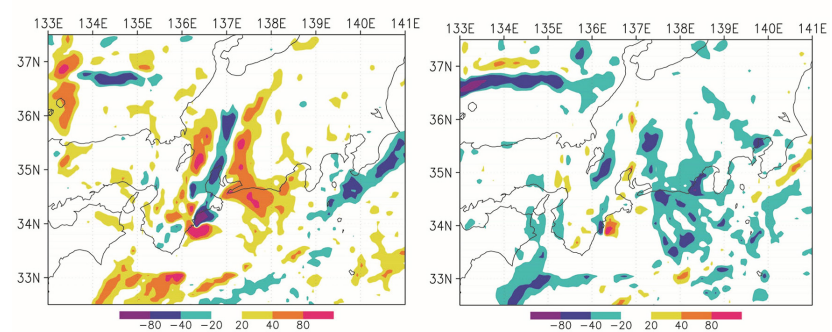

Figure 18. Distributions of anomalies (color shading) with respect to the ensemble mean for 7 days (00:00 UTC, 30 August to 6 September 2011) for accumulated precipitation ( $\mathrm{mm}$ ) in (a) Exp. WK and (b) Exp. AV (Domain 2).

main Japanese islands, and northerly after the landing. The surface wind speed is greater than $10 \mathrm{~m} \mathrm{~s}^{-1}$ and southeasterly is predominant, when the cyclone brings heavy rain in Japan (1 to 4 Sempember, Fig. 10). The enhanced surface wind leads to the amplification of the surface latent heat flux, whereas the air-sea difference of water vapor mixing ratio is nearly constant $\left(\sim 2 \mathrm{~g} \mathrm{~kg}^{-1}\right.$ in 31 August to 4 September). The surface latent heat flux rapidly increases at around 00:00 UTC, 6 September, as both air-sea differences of wind and water vapor mixing ratio are enhanced via the strong northerly advection of dry air mass from the land. At 00:00 UTC, 5 September, the surface latent heat flux is small because the wind temporarily weakens. Time evolutions of anomalies of the surface latent heat flux in Exp. WK and Exp. AV correlate with those of $U_{10 \mathrm{~m}}$ and $q_{\mathrm{sat}}-q_{2} \mathrm{~m}$, although the wind anomaly includes noisy fluctuation with large amplitude. For surface sensible heat flux, the ensemble mean and anomalies highly correlate with those of the airsea temperature difference. The ensemble mean sensible heat flux and air-sea temperature difference are negative (positive), when the warm southerly (cold northerly) wind blows around 3 September (6 September).

The SST anomaly is enhanced on around 3 September, when the southeasterly wind is strong. The temporarily enhanced SST anomaly produces the large anomalies of the surface latent and sensible heat fluxes via the air-sea difference in wind, water vapor, and temperature. Thus, the time 
(a)
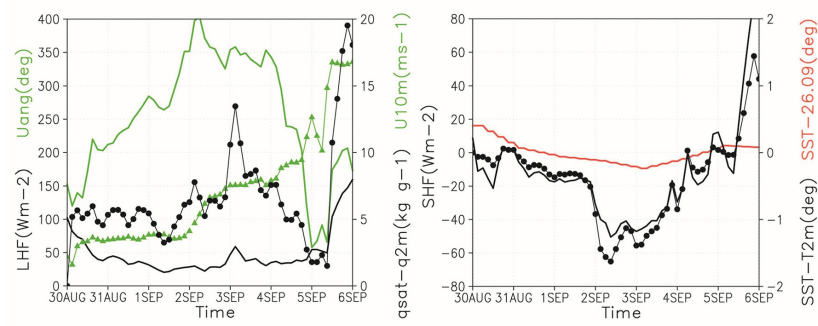

(b)
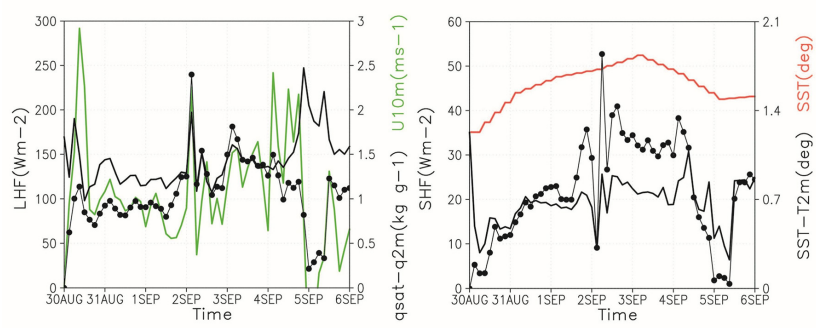

(c)
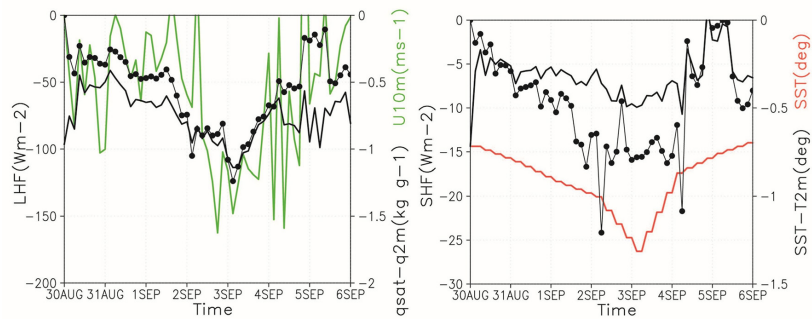

Figure 19. Time series of (a) the ensemble means, (b) anomalies in Exp. WK, and (c) anomalies in Exp. AV for SST ( ${ }^{\circ}$, thick red lines), surface wind direction $\left(^{\circ}\right.$, green solid triangles), magnitude $\left(\mathrm{m} \mathrm{s}^{-1}\right.$, thick green lines), surface latent heat flux $\left(\mathrm{W} \mathrm{m}^{-2}\right.$, solid black circles in left panels), air-sea difference of water vapor mixing ratio ( $\mathrm{g} \mathrm{kg}^{-1}$, thick black lines in left panels), surface sensible heat flux ( $\mathrm{W} \mathrm{m}^{-2}$, solid black circles in right panels), and air-sea difference of temperature ( $\mathrm{K}$, thick black lines in right panels), obtained from the model outputs in Domain 2 for the six experiments.

evolution of the coastal SST anomaly also influences the surface latent and sensible heat fluxes.

The surface wind direction changes with time from southerly to northerly. Thus, the southeasterly air mass is $1 \mathrm{~K}$ warmer than the sea surface on around 3 September, and the northerly air mass is colder than the sea surface on 5 September. This indicates that the negative temperature difference on around 2 to 3 September is offset by the positive one in 5 September. Thus, the offset of negative air-sea temperature difference leads to the small 7-day accumulated surface sensible heat flux. On the other hand, a large difference between $q_{\mathrm{sat}}$ and $q_{2 \mathrm{~m}}$ can be maintained during the simulation because the unsaturated air mass is transported to the coastal region, irrespective of the wind directions. Thus, the maintenance of both the large air-sea difference in water vapor mixing ratio and the strong surface wind lead to the large 7-day accumulated surface latent heat flux.
Table 6. Ensemble means and anomalies of 7-day averaged surface meteorological elements at $33.0^{\circ} \mathrm{N}, 138.5^{\circ} \mathrm{E}$.

\begin{tabular}{lrrrrr}
\hline $\begin{array}{l}\text { Quantity } \\
\text { Unit }\end{array}$ & $\begin{array}{r}\mathrm{SST} \\
{ }^{\circ} \mathrm{C}\end{array}$ & $\begin{array}{r}T_{2 \mathrm{~m}} \\
{ }^{\circ} \mathrm{C}\end{array}$ & $\begin{array}{r}q_{\text {sat }} \\
\mathrm{g} \mathrm{kg}^{-1}\end{array}$ & $\begin{array}{r}q_{2 \mathrm{~m}} \\
\mathrm{~g} \mathrm{~kg}^{-1}\end{array}$ & $\begin{array}{r}U_{10 \mathrm{~m}} \\
\mathrm{~m} \mathrm{~s}^{-1}\end{array}$ \\
\hline Mean & 27.52 & 27.53 & 23.70 & 20.38 & 13.14 \\
Exp. RL & +0.13 & +0.07 & +0.18 & +0.02 & +0.13 \\
Exp. RH & +0.16 & +0.08 & +0.23 & +0.05 & +0.15 \\
Exp. WK & +0.15 & +0.12 & +0.21 & +0.06 & +0.20 \\
Exp. AV & -0.11 & -0.11 & -0.16 & +0.02 & -0.11 \\
Exp. AA & -0.24 & -0.13 & -0.34 & -0.09 & -0.32 \\
Exp. NG & -0.08 & -0.04 & -0.13 & -0.07 & -0.04 \\
\hline
\end{tabular}

Figure 20 shows the time-height cross sections of the ensemble mean quantities (wind, potential temperature, and vapor mixing ratio) and their anomalies in Exp. WK and Exp. AV at the representative point $\left(34^{\circ} \mathrm{N}, 136.8^{\circ} \mathrm{E}\right)$. The pressure is approximated by $1000 \times \eta$. In Exp. WK, the anomalies of wind speed are positive near the surface and negative around $950 \mathrm{hPa}$. The wind anomaly structure is broken on around 2 September (abrupt outbreak) and 5 September (rapid weakening of wind), and the anomalies are extended to upper levels. The temperature anomaly is predominant below the $950 \mathrm{hPa}$ level. The temperature anomalies are extended to upper levels on around 2 and 5 September. Near the surface below the isotherm of $302 \mathrm{~K}$, the positive anomaly of water vapor mixing ratio is seen. In Exp. AV, the signs of the anomalies are opposite those in Exp. WK. The anomalies of wind speed are positive (negative) near the surface $(950 \mathrm{hPa})$. The negative anomalies of temperature and water vapor are continuously seen near the surface.

The magnitudes and standard errors of the sea-surface latent flux and precipitation are high when the cyclone is located around Japan (Fig. 10). In particular, around the southern coast of Japan, the large error of $>10 \mathrm{~W} \mathrm{~m}^{-2}$ for the latent heat flux is maintained. As shown in Fig. 19b-c, the anomaly of the surface latent heat flux increases during 2 to 4 September at the representative point of the large SST anomaly. This implies that the differences in the 7-day accumulated sea-surface latent flux and precipitation are produced mainly when the cyclone passes over Japan. Although the 7-day standard errors of wind, temperature, and water vapor decrease with height, the abrupt changes are seen in upper levels (Fig. 20). Thus, the precipitation anomaly may become more complex via the temporal changes of temperature and water vapor at upper levels.

\section{Concluding remarks}

This paper investigated the influences of the weekly SST anomaly on 7-day accumulated coastal meteorological elements in the presence of the humid airflow from the Tropical Cyclone Talas (2011). Sensitivity simulations using 3-D 
grid nudging of temperature, wind, and water vapor were performed using six SST products covering a period of 7 days. In this case, high upward latent heat flux predominated around the Kuroshio. The 7-day averaged humid airflow near the surface was forced to flow east-southeasterly by the high mountains of the main Japanese islands, and led to heavy precipitation over the Kii Peninsula.

Although the SST anomaly does not significantly influence some meteorological elements (wind, temperature, and water vapor), it does have a major effect on the accumulated evaporation and precipitation. Week-long anomalies of around $1{ }^{\circ} \mathrm{C}$ in the SST products were found in the cold coastal waters south of Japan $\left(<27^{\circ} \mathrm{C}\right.$ around $34^{\circ} \mathrm{N}$, $138^{\circ} \mathrm{E}$ ) because it is technically difficult to accurately estimate the coastal SST. The large positive (negative) anomalies of coastal SST induce positive (negative) differences in accumulated latent heat fluxes. The large positive anomaly of the latent heat flux enhances the positive anomaly of the surface wind speed via vertical momentum mixing from the $950 \mathrm{hPa}$ level southeasterly wind, which contributes to the enhancement of the latent heat flux itself. This implies a positive feedback between surface latent heat flux and horizontal wind.

The present work emphasizes that the uncertainty in SST products leads to large uncertainties in coastal evaporation and precipitation. In particular, the warm SST anomaly enhances the precipitation around mountain slopes, and weakens the precipitation over the small plains between the mountainsides. In addition, the present work suggests that the SST anomaly temporarily influences the upper-level atmosphere and thus the precipitation anomaly may become more complex via the temporal changes of temperature and water vapor at upper levels (the $850 \mathrm{hPa}$ level and higher). As the significant impact of the SST anomaly on 7-day accumulated precipitation over the mountainsides is important in hazard risk management associated with tropical cyclones (e.g., landslides and floods), further coastal sea monitoring and accurate SST estimates (e.g., atmosphere-ocean coupling and coastal ocean data assimilation) are required to improve the forecasting of coastal precipitation and evaporation.
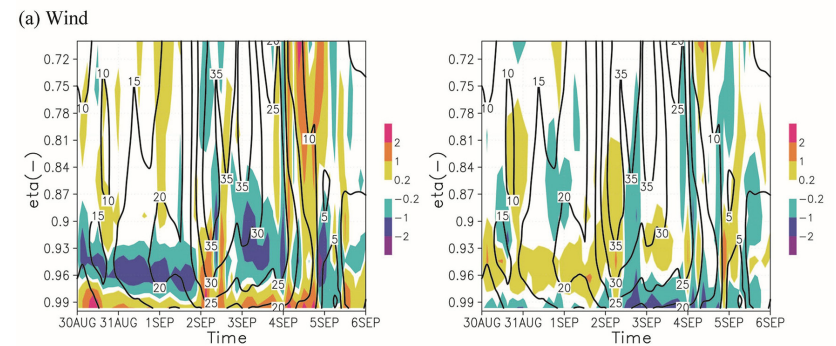

(b) Pot. Tmp.
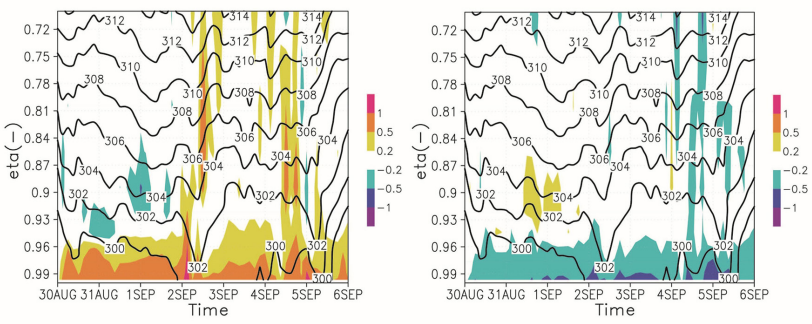

(c) Vapor
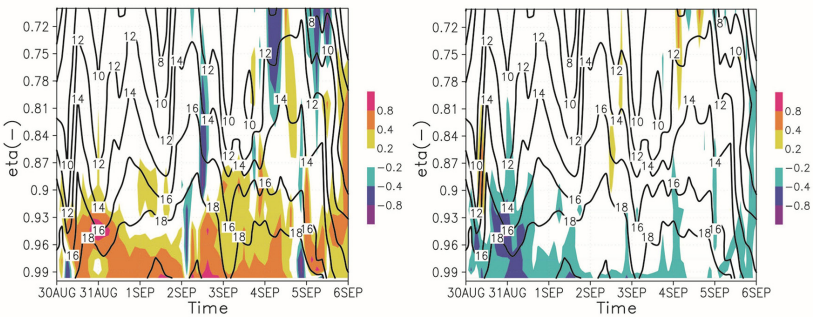

Figure 20. Time-vertical cross sections of (a) horizontal wind $\left(\mathrm{m} \mathrm{s}^{-1}\right)$, (b) potential temperature $(\mathrm{K})$, and (c) water vapor mixing ratio $\left(\mathrm{g} \mathrm{kg}^{-1}\right)$, obtained from the model outputs in Domain 2 for the six experiments in Exp. WK (left panels) and Exp. AV (right panels). The contours and color shadings show the ensemble means and anomalies, respectively. The pressure ( $\mathrm{hPa}$ ) is approximated by $1000 \times \eta$. 


\section{Appendix A: Influence of water vapor nudging} on precipitation

Figure A1 shows the weekly precipitations for the experiments (a) without nudging of wind, temperature, and water vapor, and (b) with nudging of wind and temperature (not including water vapor nudging) in Domain 1. Compared with Fig. 11b, precipitation was underestimated over the Kii Peninsula in these two experiments. Consequently, the present work focuses on experiments that include the nudging of wind, temperature, and water vapor to simulate realistic precipitation over the Kii Peninsula.

(a)

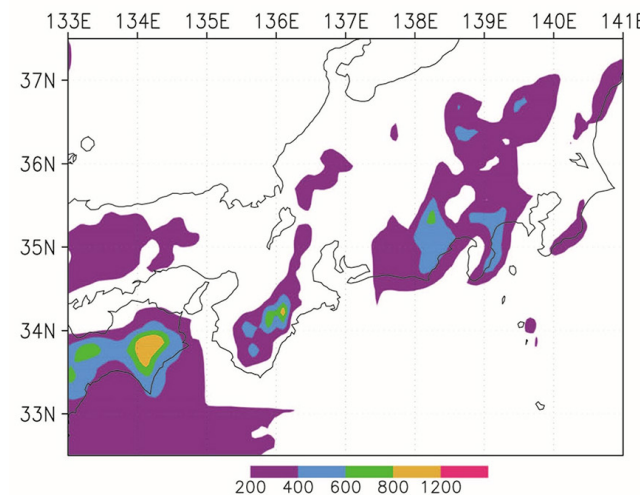

(b)

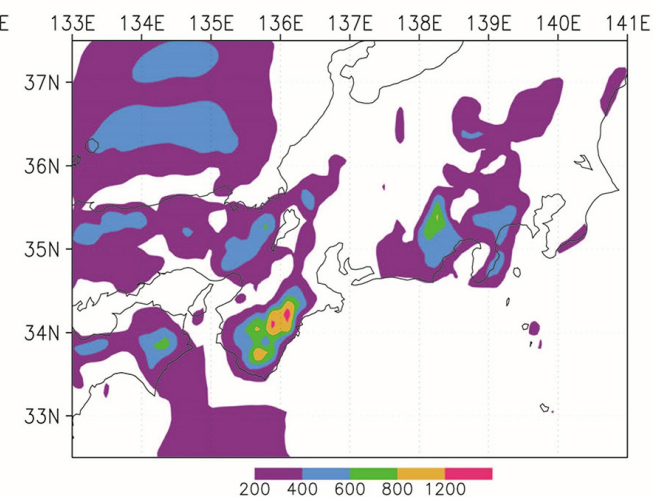

Figure A1. Distributions of the ensemble mean precipitation for 7 days (00:00 UTC, 30 August to 6 September 2011) for the experiments (a) without nudging of wind, temperature, and water vapor, and (b) with nudging of wind and temperature (not including water vapor nudging). The model results are obtained from the output in Domain 2. 
Acknowledgements. The author thanks Petros Katsafados and anonymous reviewers for helping to improve earlier versions of this paper. This study is part of a Kyushu University project entitled "Understanding Influences of Global Warming and Rapid Economical Development on the East Asia Marine and Atmospheric Environment", and was supported by a MEXT/JSPS Grant-inAid for Scientific Research on Innovative Areas (KAKENHI grant no. 22106003). Data were sourced from the Japan Meteorological Agency, the US Climate Prediction Center, the US National Centers for Atmospheric Research and for Environmental Prediction, the US National Oceanic and Atmospheric Administration, and Tohoku University, Japan.

Topical Editor V. Kotroni thanks P. K. Katsafados and one anonymous referee for their help in evaluating this paper.

\section{References}

Cha, Y.-M., Lee, H.-W., and Lee, S.-H.: Impacts of the highresolution sea surface temperature distribution on modeled snowfall formation over the Yellow Sea during a cold-air outbreak, Weather Forecast., 26, 487-503, 2011.

Chen, F. and Dudhia, J.: Coupling an advanced landsurface/hydrology model with the Penn State/NCAR MM5 modeling system. Part I: model description and implementation, Mon. Weather Rev., 129, 569-585, 2001.

Chen, T.-C., Chang, C.-B., and Perkey, D. J.: Numerical study of an AMTEX '75 ocean cyclone, Mon. Weather Rev., 111, 18181829, 1983.

Dudhia, J.: Numerical study of convection observed during the winter monsoon experiment using a mesoscale two-dimensional model, J. Atmos. Sci., 46, 3077-3107, 1989.

Hayes, S. P., McPhaden, M. J., and Wallace, J. M.: The influence of sea-surface temperature on surface wind in the eastern equatorial Pacific: weekly to monthly variability, J. Climate, 2, 1500-1506, 1989.

Hong, S.-Y. and Lim, J.-O. J.: The WRF single-moment 6-class microphysics scheme (WSM6), J. Korean Meteorol. Soc., 42, 129151, 2006.

Hong, S.-Y., Noh, Y., and Dudhia, J.: A new vertical diffusion package with an explicit treatment of entrainment processes, Mon. Weather Rev., 134, 2318-2341, 2006.

Iizuka, S.: Simulations of wintertime precipitation in the vicinity of Japan: Sensitivity to fine-scale distributions of sea surface temperature, J. Geophys. Res., 115, D10107, doi:10.1029/2009JD012576, 2010.

Japan Meteorological Agency: Heavy precipitation caused by Tropical Cyclone Talas (2011) on 30 August to 6 September 2011, Preliminary report for weather hazard, 19 pp., 2011.

Kain, J. S.: The Kain-Fritsch convective parameterization: An update, J. Appl. Meteorol., 43, 170-181, 2004.

Katsafados, P., Mavromatidis, E., Papadopoulos, A., and Pytharoulis, I.: Numerical simulation of a deep Mediterranean storm and its sensitivity on sea surface temperature, Nat. Hazards Earth Syst. Sci., 11, 1233-1246, doi:10.5194/nhess-111233-2011, 2011.

Lee, S.-H. and Ryu, C.-R.: Influence of continuous satellite-based SST distribution on heavy snowfall events over the Korean Peninsula, Int. J. Remote Sens., 31, 2853-2883, 2010.

Liu, P., Tsimpidi, A. P., Hu, Y., Stone, B., Russell, A. G., and Nenes, A.: Differences between downscaling with spectral and grid nudging using WRF, Atmos. Chem. Phys., 12, 3601-3610, doi:10.5194/acp-12-3601-2012, 2012.

Mlawer, E. J., Taubman, S. J., Brown, P. D., Iacono, M. J., and Clough, S. A.: Radiative transfer for inhomogeneous atmosphere: RRTM, a validated correlated-k model for the longwave, J. Geophys. Res., 102, 16663-16682, 1997.

Reynolds, R. W., Rayner, N. A., Smith, T. M., Stokes, D. C., and Wang, W.: An improved in situ and satellite SST analysis for climate, J. Climate, 15, 1609-1625, 2002.

Reynolds, R. W., Smith, T. M., Liu, C., Chelton, D. B., Casey, K. S., and Schlax, M. G.: Daily high-resolution-blended analyses for sea surface temperature, J. Climate, 20, 5473-5496, 2007.

Sakaida, F., Kawamura, H., Takahashi, S., Shimada, T., Kawai, Y., Hosoda, K., and Guan, L.: Research and development of the new generation sea surface temperature for open ocean (NGSST-O) product and its demonstration operation, J. Oceanogr., 65, 859870, 2009.

Skamarock, W. C., Klemp, J. B., Dudhia, J., Gill, D. O., Barker, D. M., Duda, M. G., Huang, X.-Y., Wang, W., and Powers, J. G.: A description of the Advanced Research WRF Version 3, NCAR Tech Note, NCAR/TN-475+STR, 126 pp., 2008.

Takahashi, H. G., Ishizaki, N. N., Kawase, H., Hara, M., Yoshikane, T., Ma, X., and Kimura, F.: Potential impact of sea surface temperature on winter precipitation over the Japan Sea side of Japan: a regional climate modeling study, J. Meteorol. Soc. Jpn, 90, 471-488, 2013.

Thiébaux, J., Rogers, E., Wang, W., and Katz, B.: A new highresolution blended real-time global sea surface temperature analysis, B. Am. Meteorol. Soc., 84, 645-656, 2003.

Wallace, J. M., Mitchell, T. P., and Deser, C.: The influence of seasurface temperature on surface wind in the eastern equatorial $\mathrm{Pa}$ cific: seasonal and interannual variability, J. Climate, 2, 1492 1499, 1989.

Wu, C.-C., Lee, C.-Y., and Lin, I.-I.: The effect of the ocean eddy on tropical cyclone intensity, J. Atmos. Sci., 64, 3562-3578, 2007.

Xie, J., Zhu, J., and Li, Y.: Assessment and inter-comparison of five high-resolution sea surface temperature products in the shelf and coastal seas around China, Cont. Shelf. Res., 28, 1286-1293, 2008.

$\mathrm{Xu}, \mathrm{H}$. , Tokinaga, H., and Xie, S.-P.: Atmospheric effects of the Kuroshio large meander during 2004-05, J. Climate, 23, 47044715, 2010.

Yamamoto, M. and Hirose, N.: Impact of SST reanalyzed using OGCM on weather simulation: A case of a developing cyclone in the Japan-Sea area, Geophys. Res. Lett., 34, L05808, doi:10.1029/2006GL028386, 2007.

Yamamoto, M. and Hirose, N.: Influence of assimilated SST on regional atmospheric simulation: A case of a cold-air outbreak over the Japan Sea, Atmos. Sci. Lett., 9, 13-17, 2008.

Yamamoto, M. and Hirose, N.: Regional atmospheric simulation of monthly precipitation using high-resolution SST obtained from an ocean assimilation model: Application to the wintertime Japan Sea, Mon. Weather Rev., 137, 2164-2174, 2009.

Yamamoto, M., Ohigashi, T., Tsuboki, K., and Hirose, N.: Cloudresolving simulation of heavy snowfalls in Japan for late December 2005: application of ocean data assimilation to a snow disaster, Nat. Hazards Earth Syst. Sci., 11, 2555-2565, doi:10.5194/nhess-11-2555-2011, 2011. 